\title{
CRIME, IMMIGRATION, AND AD HOC INSTRUMENTALISM
}

\author{
David Alan Sklansky*
}

Criminal law and immigration law, once separate fields of governance in the United States, are rapidly growing less distinct. Immigration crimes now account for a majority of all federal prosecutions; deportation is widely seen as a key tool of crime control; immigration authorities run the nation's largest prison system; and state and local law enforcement officers work hand-in-hand with federal immigration officials. This article traces these trends and assesses their significance. The rise of an intertwined regime of "crimmigration" law has generally been attributed to some combination of nativism, overcriminalization, and a cultural obsession with security, but it also exemplifies, and has helped to reinforce, a crucial and underappreciated development in U.S. legal culture-a rising tendency to treat legal rules and legal procedures as interchangeable tools, to be brought to bear pragmatically and instrumentally on an ad hoc basis. Ad hoc instrumentalism of this kind has genuine strengths, but it also raises significant concerns about the rule of law and political accountability. The accountability concerns, in particular, are exacerbated by two other features of our newly merged system of immigration enforcement and criminal justice: its bureaucratic opacity and its selective application.

*Yosef Osheawich Professor of Law, University of California, Berkeley. I thank Kunti Dudakia, Rosha Jones, Camille Pannu, and Quinn Rotchford for research assistance, Joanna Lydgate and John Simanski for tutoring, and Sarah Lawrence and the Berkeley Center for Criminal Justice for help with data collection and analysis. I received valuable comments and criticism from Lisa Kern Griffin, Alice Hill, Kristen Holmquist, Máximo Langer, Sarah Lawrence, David Lieberman, David Martin, Allegra McLeod, Daniel Richman, Sarah Song, Leti Volpp, Frank Zimring; workshop participants at Berkeley, Duke, and George Washington University; and anonymous reviewers for this journal. All errors and opinions are mine.

New Criminal Law Review, Vol. I5, Number 2, pps 157-223. ISSN 1933-4192, electronic ISSN 1933-4206. (C) 2012 by the Regents of the University of California. All rights reserved. Please direct all requests for permission to photocopy or reproduce article content through the University of California Press's Rights and Permissions website, http://www.ucpressjournals. com/reprintInfo.asp. DOI: I0.I525/nclr.2012.15.2.157. 
Keywords: crime, immigration, instrumentalism, parole, rule of law, accountability

\section{INTRODUCTION}

When my grandparents arrived at Ellis Island a century ago, their entry into the United States was governed by immigration law, not by criminal law. In one sense, of course, immigration enforcement and criminal justice have always overlapped: they tend to focus on similar groups of outsiders. The poor, the desperate, and the racially disfavored are more likely to seek admission to the United States, more likely to encounter resistance to their entry and continued residence, and for many of the same reasons, more likely to come into contact with the criminal justice system-as victims, suspects, defendants, and convicted felons. As a formal matter, though, immigration law and criminal law used to be entirely separate. Immigration law supplied rules and procedures for deciding who could enter the United States, when if ever they needed to leave, and under what circumstances they could become citizens. Criminal law provided rules and procedures for determining who had committed a crime and what should happen to them. Violating immigration rules was not a crime; it could result in deportation but not in a prison sentence. Crimes, conversely, were punishable by imprisonment but not by deportation. Immigration laws were enforced by federal immigration officials, and violations were adjudicated in immigration hearings. Criminal laws were enforced by police officers, almost entirely at the local level, and prosecuted for the most part in state courts. ${ }^{1}$

Today that world is gone. Immigration law and criminal law continued to operate largely independently for much of the twentieth century, but over the past three decades the two fields have become increasingly intertwined. Immigration cases now are not only the largest category of federal criminal prosecutions; they are a majority of federal criminal prosecutions. ${ }^{2}$

I. See, e.g., Daniel Kanstroom, Deportation, Social Control, and Punishment: Some Thoughts About Why Hard Laws Make Bad Cases, n3 Harv. L. Rev. 1890 (2000).

2. See Transactional Records Access Clearinghouse, FY 2009 Federal Prosecutions Sharply Higher: Surge Driven by Steep Jump in Immigration Filings (2009), trac.syr.edu; Joanna Lydgate, Chief Justice Earl Warren Institute on Race, Ethnicity \& Diversity, Assembly-Line Justice: A Review of Operation Streamline (2009). 
Meanwhile tens of thousands of aliens are deported every year because of criminal convictions or suspicion of criminal activity; the "criminal alien" has become the central, overriding concern of immigration authorities. ${ }^{3}$ A vast network of administrative holding facilities has emerged for individuals accused of immigration violations, paralleling and regularly exchanging prisoners with the jails, prisons, and other criminal correctional institutions operating at the federal, state, and local levels. ${ }^{4}$ And local police agencies, for their part, increasingly work hand-in-hand with federal immigration officials. ${ }^{5}$

Immigration enforcement and criminal justice are now so thoroughly entangled it is impossible to say where one starts and the other leaves off; growing numbers of practitioners describe themselves as working in the merged field of "crimmigration." "Bowing to the new reality, the Supreme Court ruled in 2010 that deportation is so "intimately related to the criminal process" that a criminal defendant's constitutional right to the effective assistance of counsel can be violated by a defense attorney's failure to warn about the immigration consequences of pleading guilty. ${ }^{7}$

A small but growing body of academic commentary examines the blurred boundary between immigration enforcement and criminal justice, and speculates about its causes. ${ }^{8}$ These articles draw attention to the

3. See, e.g., Stephen H. Legomsky, The New Path of Immigration Law: Asymmetric Incorporation of Criminal Justice Norms, 64 Wash. \& Lee L. Rev. 469 (2007); Teresa A. Miller, Citizenship \& Severity: Recent Immigration Reforms and the New Penology, 17 Geo. Immigr. L.J. 6II (2003).

4. See William J. Sabol, Heather C. West, \& Matthew Cooper, U.S. Bureau of Justice Statistics, Prisoners in 2008 (2009); Transactional Records Access Clearinghouse, Huge Increase in Transfers of ICE Detainees (2009), trac.syr.edu.

5. See, e.g., Juliet P. Stumpf, States of Confusion: The Rise of State and Local Power Over Immigration, 86 N.C. L. Rev. 1557 (2008).

6. E.g., Jennifer Chacón, Managing Migration Through Crime, 109 Colum. L. Rev. Sidebar 135 (2009); Juliet Stumpf, The Crimmigration Crisis: Immigrants, Crime, and Sovereign Power, 56 Am. U. L. Rev. 367 (2006).

7. Padilla v. Kentucky, 130 S. Ct. 1473 (2010).

8. The leading works are by Jennifer Chacón, Daniel Kanstroom, Stephen Legomsky, Teresa Miller, and Julier Stumpf. See Chacón, supra note 6; Jennifer Chacón, A Diversion of Attention? Immigration Courts and the Adjudication of Fourth and Fifth Amendment Rights, 59 Duke L.J. 1563 (2010); Jennifer Chacón, Whose Community Shield?: Examining the Removal of the "Criminal Street Gang Member," 2007 U. Chi. Legal F. 317; Kanstroom, supra note I; Daniel Kanstroom, Criminalizing the Undocumented: Ironic Boundaries of the Post-September nth "Pale of Law," 29 N.C. J. Int'l L. \& Com. Reg. 639 
increasingly harsh criminal penalties that Congress has authorized for immigration violations, to the growing category of criminal convictions for which noncitizens face discretionary or-more and more oftenmandatory deportation, to the increasingly punitive feel of immigration proceedings, and to the expanding participation of state and local police agencies in immigration enforcement. Broadly speaking, the existing scholarship ties this set of developments to three larger trends. The first is nativism: what seems to many to be the increasingly harsh, increasingly unwelcoming, increasingly racist treatment of newcomers to the United States. The second is overcriminalization: the frequently deplored tendency of criminal law to expand into areas for which its heavy-handed machinery seems ill-suited. The third and last is a kind of cultural obsession with security, an inclination to view all social problems through the lens of crime and physical victimization-roughly speaking, what David Garland has called "the culture of control" and Jonathan Simon describes as "governing through crime."

My goal here is to add to this literature in two ways. First, I want to examine the on-the-ground dimensions of crimmigration. That is to say, I want to provide a sense of how the merged system of immigration enforcement and criminal justice is functioning, not at the level of symbolism (though the symbolism is plainly important), but at the level of actual practice. The central descriptive question I will pursue is not whether criminal law and immigration law have grown mutually enmeshed (they clearly have), not what sequence of legal changes has facilitated that entanglement (a story that has been told elsewhere), and not whether particular features of the new, merged system are unduly harsh and xenophobic (questions that other scholars have pursued thoughtfully

(2004); Legomsky, supra note 3; Miller, supra note 3; Teresa A. Miller, Blurring the Boundaries Between Immigration and Crime Control After September itth, B.C. Third World L.J. 8I (2005); Stumpf, supra note 5; Stumpf, supra note 6. For recent, valuable additions to this literature, see Ingrid V. Eagly, Prosecuting Immigration, I04 Nw. U. L. Rev. 128I (2010); Allegra M. McLeod, The U.S. Criminal-Immigration Convergence and Its Possible Undoing, 49 Am. Crim. L. Rev. __ (forthcoming).

9. David Garland, The Culture of Control: Crime and Social Order in a Contemporary Society (200I); Jonathan Simon, Governing Through Crime: How the War on Crime Transformed American Democracy and Created a Culture of Fear (2007). There are important differences between Simon's argument and Garland's, see Simon, supra, at 22-3I, but we can ignore them for present purposes. 
and, I think, persuasively). Instead, I will focus on the dimensions and the macro-level dynamics of this emerging system: how it actually operates, and on what scale. I am particularly interested in the ways in which crimmigration is altering, expanding, and redirecting our institutions of policing and punishment. ${ }^{10}$

Second, I want to draw a connection between the rise of crimmigration and what I will call, for want of a better term, ad hoc instrumentalism. By ad hoc instrumentalism, I mean a manner of thinking about law and legal institutions that downplays concerns about consistency and places little stock in formal legal categories, but instead sees legal rules and legal procedures simply as a set of interchangeable tools. In any given situation, faced with any given problem, officials are encouraged to use whichever tools are most effective against the person or persons causing the problem. This way of thinking about the law is instrumental rather than formalistic (whether behavior should be treated as criminal, for example, depends on whether criminal procedures and sanctions will best accomplish the government's objectives, not on any abstract considerations of fit or appropriateness), and it is ad hoc as opposed to systematic (whether to invoke criminal procedures and criminal sanctions is decided case by case, based on whatever circumstances seem most compelling in that particular instance, rather than by applying a defined, across-the-board set of rules or standards). It is also increasingly commonplace, and it raises, I will argue, some important and underappreciated issues of accountability.

Ad hoc instrumentalism is linked to crimmigration in two ways. First, it has helped to create the conditions for crimmigration. Ad hoc instrumentalism is certainly not the only reason-nor, probably, the most important reason-that the line between criminal law and immigration law has blurred. Nativism and security obsession are equally if not more important. Overcriminalization may be part of the story, too, although its contribution is less clear, for reasons I will explain. But nativism, security obsession, and overcriminalization, even in combination, cannot fully explain the shape that crimmigration has taken. Ad hoc instrumentalism is the missing part of the story.

Io. My focus in this regard partly overlaps with that of Ingrid Eagly, who has stressed the way in which immigration enforcement and criminal justice have merged into a "single, integrated regulatory bureaucracy ... that blurs and reshapes law enforcement power, prosecutorial incentives, and the aims of the criminal law." See Eagly, supra note 8. 
Second, aside from its explanatory value, ad hoc instrumentalism is a defining feature of the emerging system of crimmigration. The boundary between criminal law and immigration law has blurred in a particular way: it has grown increasingly dependent on ad hoc, instrumental decision making. That matters, because it means that among the issues raised by crimmigration are issues of accountability. Those issues are particularly acute, I will argue, because of two related characteristics of our new, merged system of criminal justice and immigration enforcement. One is selectivity: the fact that immigration law now provides, in effect, an alternative system of criminal punishment, but only for a particular, racially lopsided fraction of the United States population. The other is opacity: the difficulty of pinpointing responsibility for the treatment of people caught up in the crimmigration system, and even for across-the-board policies adopted by components of that system.

Just as crimmigration does not owe its rise solely to ad hoc instrumentalism, so ad hoc instrumentalism is not limited to the context of crimmigration. Neither is selectivity or bureaucratic opacity, for that matter. Nonetheless, the blurred boundary between criminal justice and immigration enforcement is a particularly vivid manifestation of ad hoc instrumentalism, and it usefully illustrates both the allures and the dangers of this approach to law and legal institutions.

Part I of this article will describe the various ways in which criminal justice and immigration enforcement have grown increasingly intertwined, paying special attention to the large-scale dynamics of what is increasingly a merged system of rules, procedures, and sanctions. I will downplay here issues of symbolism and rhetoric-the potent, racially charged image of the "criminal alien," for example, or the cultural significance of calling a government program "Secure Communities" — not because I think they are unimportant, but because they have been explored elsewhere, and they are peripheral to the points I want to pursue here. So I will be less interested in new criminal penalties added to the statute books and more interested in the actual criminal prosecution of immigration violations. I will focus less on what Congress has said about the immigration consequences of criminal convictions than on the actual use of immigration law as a tool of crime control. I will pay less attention to the use of the symbolism and rhetoric of criminal law in immigration proceedings than to a particular, concrete practice that immigration law has imported from criminal law: routine incarceration. And I will attempt to determine, as well as I can, the 
actual extent of the involvement of local police departments in immigration enforcement.

With this background, Part II of the article will introduce the concept of ad hoc instrumentalism, discuss its growing prevalence, and examine the ways in which it helps to explain the disappearing line between criminal justice and immigration enforcement. I argue that ad hoc instrumentalism complements, but does not replace, the more familiar explanations of crimmigration-nativism, overcriminalization, and security obsession.

Part III will turn from the drivers of crimmigration to the significance of the phenomenon and the concerns it should raise for the rule of law and, more particularly, for political accountability. For crimmigration has blurred not only the boundary line between criminal justice and immigration enforcement but also the lines of responsibility within the new, merged field of governance. In part this is a direct consequence of ad hoc instrumentalism - the idea that low-level officials should be empowered and encouraged to select among enforcement regimes opportunistically, on a case-by-case basis. The accountability issues raised by crimmigration are exacerbated, though, by two of its other features: the selective reach of immigration as an alternative regime of policing and criminal sanctioning, and the opacity of the merged system of criminal justice and immigration enforcement. It turns out that these features of crimmigration are themselves linked in some ways to ad hoc instrumentalism. The discussion in Part III will therefore be partly about the concerns raised by ad hoc instrumentalism throughout the criminal justice system, not only at its intersection with immigration enforcement.

\section{THE VANISHING BOUNDARY}

Criminal justice and immigration enforcement used to be separated in four critical respects: immigration violations were not prosecuted as crimes; criminal activity was not punished by deportation; immigration proceedings were administrative rather than criminal in character; and local police officers did not enforce immigration laws. None of these propositions remain true today; that is why the line between criminal justice and immigration enforcement has all but disappeared. It is now common for immigration violations to be prosecuted as crimes, for 
criminal activity to be punished by deportation, for immigration proceedings to have the character of criminal cases, and for local police to assist actively in the enforcement of immigration laws. All of this has happened the way Mike Campbell went bankrupt: "[g]radually and then suddenly." boundary between criminal law and immigration law began to blur in the I920s, but remained reasonably distinct through the I970s. In the 1980s things began to change dramatically, and the changes accelerated after September II, 200 .

\section{A. Criminal Prosecution of Immigration Violations}

In 1929, Congress made illegal entry into the United States a misdemeanor and illegal entry following deportation a felony. ${ }^{12}$ Illegal reentry following deportation became a separate, more serious offense in $1952 .{ }^{13}$ But there were relatively few prosecutions for these offenses, or for other immigration-related crimes, until the I980s. Beginning in the 1980s, two things happened. First, Congress began enacting more and more criminal statutes aimed at illegal immigration, defining new crimes and increasing the penalties for existing crimes. Second, and more important, prosecutions for immigration crimes started to proliferate dramatically.

Many of the new crimes and increased penalties came in a series of omnibus, election-year statutes targeting illegal immigration, violent

II. Ernest Hemingway, The Sun Also Rises I4I (1926) (paperback ed. 2006).

12. See Act of Mar. 4, 1929, Pub. L. No. 70-1018, 45 Stat. 1551; Mae M. Ngai, The Strange Career of the Illegal Alien: Immigration Restriction and Deportation Policy in the United States, 1921-1965, 21 Law \& Hist. Rev. 69, 76 (2003). Counterfeiting immigration documents, or obtaining them by fraud, had been made a felony five years earlier. See Immigration Act of 1924, Pub. L. 68-139, $\$ 22,43$ Stat. 153, 165; superseded by Act of June 25, 1948, Pub. L. No. 80-772, $\$ 1542,65$ Stat. 683, 771; codified as amended at 18 U.S.C. $\$$ 1542. The Passport Act of 1918, Pub. L. No. 65-154, ch. 81, 40 Stat. 559, authorized a twenty-year sentence for entering the United States without a passport, but when the government tried to use this statute to prosecute immigration violations in peacetime, the Eighth Circuit called a halt to the practice. The court explained: "It has never been the policy of this Government to punish criminally aliens who come here in contravention of our immigration laws. Deportation has been the remedy." Flora v. Rustad, 8 F.2d 335, 337 (8th Cir. 1925); see Eagly, supra note 8.

I3. Immigration and Nationality Act of 1952, Pub. L. No. 414, tit. II, ch. 8, \$276, 66 Stat. 163, 229 (codified as amended at 8 U.S.C. 1326 (1996)); see Doug Keller, Why the Prior Conviction Sentencing Enhancements in Illegal Re-entry Cases are Unjust and Unjustified (and Unreasonable Too), si B.C. L. Rev. 719, 729 (2010). 
crime, and drug trafficking. The Immigration Reform and Control Act of 1986, which barred employers from knowingly hiring or continuing to employ noncitizens who were not authorized to work, also criminalized the use false documents to evade the employer sanctions. ${ }^{14}$ The Immigration Marriage Fraud Amendments, passed the same year, made it a felony to marry for the purpose of evading immigration laws. ${ }^{15}$ The Anti-Drug Abuse Act of 1988 raised the criminal penalties for unlawful reentry following deportation, if the deportation resulted from a felony conviction, and for aiding the illegal entry of aliens previously convicted of "aggravated felonies" or known to be entering the country illegally. ${ }^{16}$ The maximum sentence for illegal reentry was previously two years; the I988 law raised this to five years for defendants previously convicted of a felony and fifteen years for defendants previously convicted of an "aggravated felony." 17 (We will return to the category of "aggravated felonies"; it plays a large and growing role in the merger of criminal justice and immigration enforcement.) The Immigration Act of 1990 raised the sentences for harboring undocumented aliens and for aiding the entry of noncitizens inadmissible on national security grounds; it also created a new felony of "immigration-related entrepreneurship fraud." 18 The Violent Crime Control and Law Enforcement Act of 1994 raised sentences for immigration-related employment fraud, various types of passport and visa fraud, and assisting noncitizens to enter the country illegally; it also boosted, again, the penalties for illegal entry after a deportation following a criminal conviction. ${ }^{19}$ The Illegal Immigration Reform and Immigrant Responsibility Act of 1996 again raised penalties for assisting noncitizens to enter the country illegally, and it created a raft of new immigration crimes, including driving above the speed limit when fleeing an immigration checkpoint, failing to disclose

14. Immigration Reform and Control Act of 1986, Pub. L. No. 99-603, $\$$ 103(a), 100 Stat. 3359, 3380; codified as amended at 18 U.S.C. $\$ 1546(\mathrm{~b})$.

15. Immigration Marriage Fraud Amendments of 1986, Pub. L. No. 99-639, $\$ 2$ (d), 100 Stat. 3537; codified as amended at 8 U.S.C. 1325(c).

16. Anti-Drug Abuse Act of 1988, Pub. L. No. 100-690, tit. VII, $\$ 7345 \& 7346$, 102 Stat. 418I, 4471; codified as amended at 8 U.S.C. $\$ 1326$ (b) \& 1327.

17. Id. at $\$ 7345,8$ U.S.C. $\$ 1326$ (2006); see Keller, supra note 13, at 731 .

18. Immigration Act of 1990, Pub. L. No. IOI-649, tit, V, $\$ \$ 122,543$ (b), 104 Stat. 4978, 4994, 5059; codified as amended at 8 U.S.C. $\$$ I325-1327.

19. Violent Crime Control and Law Enforcement Act of 1994, Pub. L. No. 103-322, tit. XIII, $\$$ 13000I(b), 108 Stat. 1796, 2023; codified as amended at 8 U.S.C. $\$ 1326$. 
Table 1. Immigration prosecutions, 1986-2009

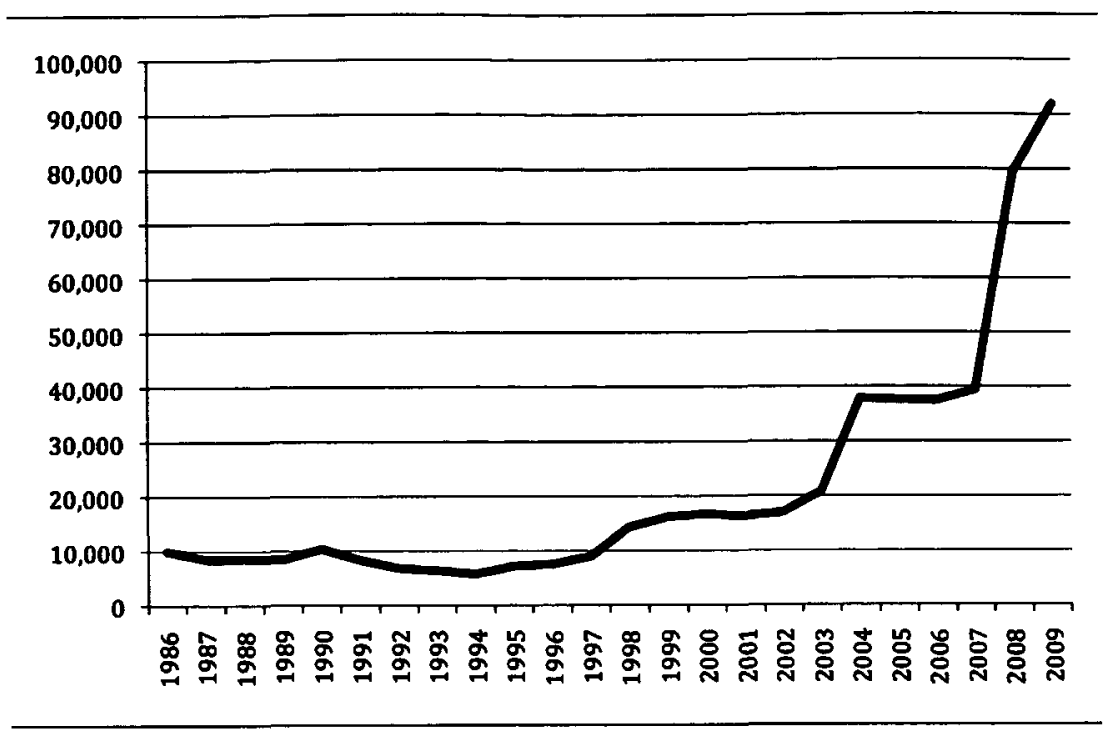

one's role in preparing a false immigration application, and filing an immigration application without a "reasonable basis in law or fact." 20

Much of this legislation was largely symbolic, a way for Congress to appear tough on illegal immigration in election years. But things have changed on the ground, as well. Prosecutions for immigration crimesespecially the various grades of illegal entry-have skyrocketed, to the point where immigration offenses account for a majority of all criminal cases in federal court. As Table 1 illustrates, immigration prosecutions began to rise slowly in the 1990s, took off dramatically in 2003 and 2004, stalled for three years, and then resumed their explosive upward trajectory. $^{21}$

Over a twelve-year period, from 1997 to 2009 , immigration prosecutions per year grew more than tenfold, from less than 9,000 to more than 90,000 . Table 2 shows that over the same period of time, the numbers for

20. Illegal Immigration Reform and Immigrant Responsibility Act of 1996, Pub. L. No. I04-208, I1o Stat. 3009-557, div. C, tit. I, $\$ 108(b)(I)$, tit. II, $\$ \$ 213$, 214; codified at 8 U.S.C. $\$ 1324 \mathrm{c}(\mathrm{e}), 18$ U.S.C. $\$ 758,1546(\mathrm{a})$.

2I. Data in Tables $1-4$ are obtained from Syracuse University's Transactional Records Access Clearinghouse, trac.syr.edu. 
Table 2. Federal prosecutions, 1986-2009

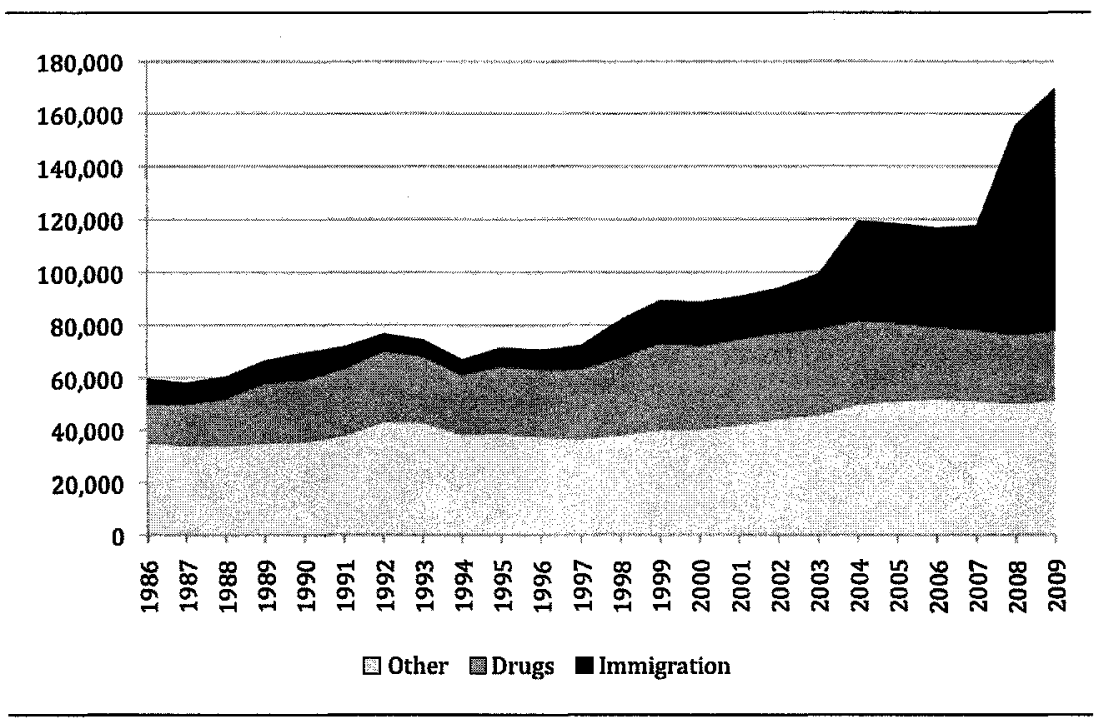

other categories of federal prosecutions were far more constant, with the result that immigration prosecutions are now not only the largest single category of federal prosecutions, they are a majority of all federal criminal cases.

As would be expected, immigration prosecutions are concentrated in states along the southwest border, but they are a large and growing share of federal prosecutions in other states, too. For example, a quarter of federal prosecutions in Idaho, Oregon, Utah, and Washington are now immigration cases. The same is true in Arkansas, Vermont, and North Dakota. Table 3 provides the share of federal prosecutions taken up by immigration cases in each state.

Table 4 breaks down the growth in immigration prosecutions according to the lead charge in each case. The lion's share of the prosecutions are for violations of 8 U.S.C. $\$$ I325 (illegal entry) and $\$ 1326$ (illegal entry following deportation). Initial violations of $\$ 1325$ are petty misdemeanors carrying a maximum sentence of six months; subsequent violations are felonies punishable by up to two years. Violation of $\$ 1326$ is a felony punishable by up to two years in prison, or significantly more if the deportation followed certain categories of criminal conviction. Together, prosecutions under $\$ \$ 1325$ and 1326 account for more than 90 percent of 
NEW CRIMINAL LAW REVIEW | VOL. 15 | NO. 2 | SPRING 2012

Table 3. Immigration cases as a percentage of federal prosecutions, 2010

\begin{tabular}{|c|c|c|c|}
\hline State & Percentage & State & Percentage \\
\hline Alabama & $5 \%$ & Montana & $6 \%$ \\
\hline Alaska & $5 \%$ & Nebraska & $18 \%$ \\
\hline Arizona & $85 \%$ & Nevada & $19 \%$ \\
\hline Arkansas & $24 \%$ & New Hampshire & $0 \%$ \\
\hline California & $52 \%$ & New Jersey & $4 \%$ \\
\hline Colorado & $27 \%$ & New Mexico & $80 \%$ \\
\hline Connecticut & $2 \%$ & New York & $15 \%$ \\
\hline Delaware & $11 \%$ & North Carolina & $8 \%$ \\
\hline Florida & $22 \%$ & North Dakota & $37 \%$ \\
\hline Georgia & $10 \%$ & Ohio & $9 \%$ \\
\hline Hawaii & $1 \%$ & Oklahoma & $8 \%$ \\
\hline Idaho & $25 \%$ & Oregon & $30 \%$ \\
\hline Illinois & $10 \%$ & Pennsylvania & $8 \%$ \\
\hline Indiana & $4 \%$ & Rhode Island & $14 \%$ \\
\hline lowa & $18 \%$ & South Carolina & $9 \%$ \\
\hline Kansas & $11 \%$ & South Dakota & $11 \%$ \\
\hline Kentucky & $5 \%$ & Tennessee & $6 \%$ \\
\hline Louisiana & $6 \%$ & Texas & $81 \%$ \\
\hline Maine & $12 \%$ & Utah & $27 \%$ \\
\hline Maryland & $6 \%$ & Vermont & $27 \%$ \\
\hline Massachusetts & $11 \%$ & Virginia & $7 \%$ \\
\hline Michigan & $13 \%$ & Washington & $23 \%$ \\
\hline Minnesota & $7 \%$ & West Virginia & $4 \%$ \\
\hline Mississippi & $5 \%$ & Wisconsin & $6 \%$ \\
\hline Missouri & $2 \%$ & Wyoming & $6 \%$ \\
\hline
\end{tabular}

all immigration prosecutions. ${ }^{22}$ Slightly more than half of the remainder are cases brought under 8 U.S.C. $\$$ 1324, which makes smuggling or harboring undocumented aliens a felony. Prosecutions under $\$$ I324 have also grown dramatically over the last decade and a half, roughly quadrupling since the early 1990s, but the number of these cases is still dwarfed by prosecutions under $\$ \$ 1325$ and 1326 .

22. As Table 4 indicates, in 2009 there were roughly twice as many prosecutions under $\$ 1325$ as under $\$ 1326$. Since then, though, the use of $\$ 1326$ has shot up, while prosecutions under $\$ 1325$ have dipped; the upshot is that is combined prosecutions under the two statutes continue to rise, but a majority of those prosecutions are now brought under $\$$ I326. Indeed, $\$ 1326$ was the most commonly recorded lead charge in federal prosecutions overall in the first half of 20Ir. See Transactional Records Access Clearinghouse, lllegal Reentry Becomes Top Criminal Charge (20II), trac.syr.edu. 
Table 4. Immigration prosecutions by statute, 1986-2009

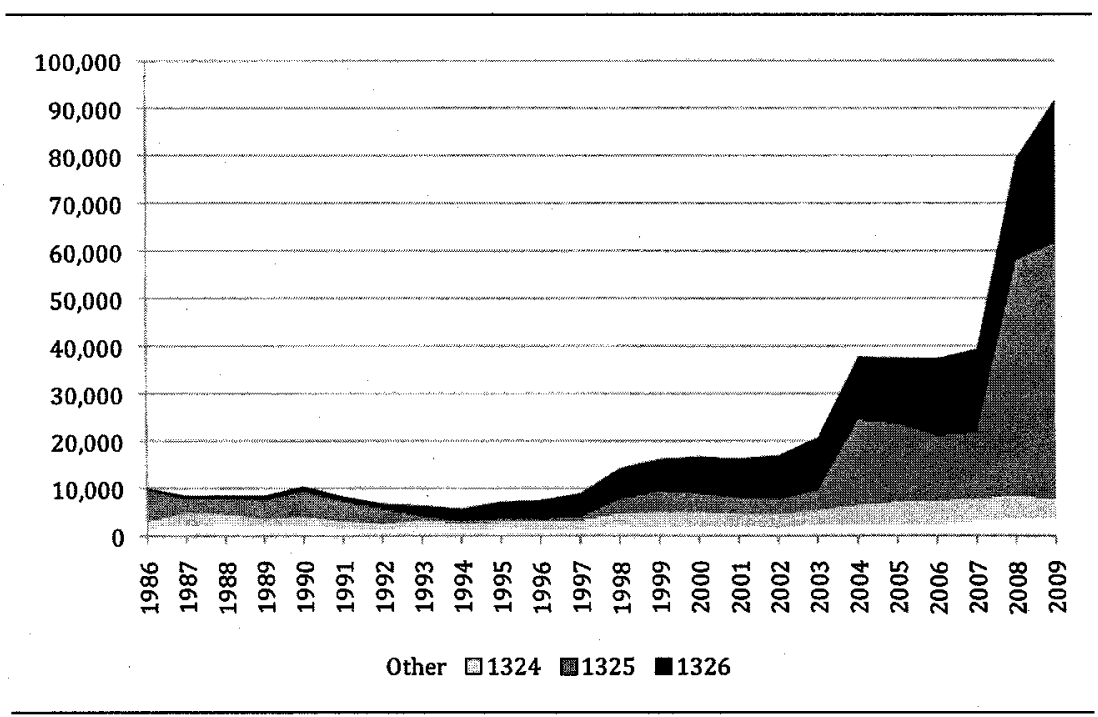

Prosecutions for illegal entry began to rise sharply in 2004. Much of the increase since that time appears attributable to a set of mass-prosecution programs often referred to as Operation Streamline. Implemented in a series of jurisdictions along the southwest border, these programs call for criminal charges to be pursued as a matter of course for people caught entering the United States illegally, rather than simply deporting them or allowing them to leave the country voluntarily. ${ }^{23}$ The first of these programs began in Del Rio, Texas, in December 2005; since then programs have been implemented in Yuma and Tucson, Arizona; Las Cruces, New Mexico; and El Paso, Laredo, McAllen, and Brownsville, Texas. ${ }^{24}$ The name "Operation Streamline" refers to the expedited and wholesale processessing of illegal entry cases in these jurisdictions; one federal judge in Las Cruces sentenced close to I,400 defendants in $2008 .^{25}$ These numbers have required abbreviated and in some cases consolidated proceedings

23. See Lydgate, supra note 2, at I-4; Chacón, Managing Migration, supra note 6 , at I $42-43$.

24. See Lydgate, supra note 2, at 3; Chacón, Managing Migration, supra note 6, at I $42-43$.

25. See Lydgate, supra note 2, at 9; see also Russell Goldman, What's Clogging the Courts? Ask America's Busiest Judge, ABC News, July 23, 2008, abcnews.go.com/ TheLaw/story?id= 5429227 \&page $=\mathbf{I}$. 
that have struck some observers—including some of the judges involved-as corner-cutting, "assembly-line justice."

For example, initial appearance, arraignment, plea, and sentencing are typically handled at a single hearing. In Tucson and Del Rio, groups of up to eighty defendants are arraigned, enter misdomeaor pleas, and are sentenced en masse; often the defendants share a single, appointed attorney. ${ }^{27}$ In 2009, the Ninth Circuit ruled that mass plea colloquys violate the requirement in Rule II of the Federal Rules of Criminal Procedure that before entry of a guilty plea, "the court must address the defendant personally in open court" and determine that the plea is knowing and voluntary. ${ }^{28}$ In the wake of that ruling, magistrate judges in Tucson and Del Rio now read the factual basis for each defendant's plea aloud and accept each defendant's plea individually, but the defedants still "appear as a group, are advised of their rights as a group, and waive their rights as a group." 29

The number of misdomeanor pleas taken under Operation Streamline has risen steadily and dramatically. Table 5 shows the number of petty immigration cases disposed of by federal magistrate judges each year, from 1997 through $2009 .^{30}$ Virtually all of these are pleas are in cases charged and disposed of under 8 U.S.C. $\$ 1325 .{ }^{31}$ The steady and dramatic increase dates from 2004, the year Operation Streamline began. ${ }^{32}$

26. Lydgate, supra note 2, at I2; see also Eagly, supra note 8.

27. See Lydgate, supra note 2 , at $4,12-14$.

28. Fed. R. Crim. P. II(b)(I) \& (2); United States v. Roblero-Solis, 588 F.3d 692 (9th Cir. 2009).

29. Lydgate, supra note 2, at I4 \& n.95; email to author from Joanna Lydgate, June 23, 20Io (on file with author).

30. Table 5 data are from statistics compiled by the Administrative Office of the United States Courts and published in its annual report, Judicial Business of the U.S. Courts, www.uscourts.gov/Statistics/JudicialBusiness.aspx. Through 1999, the number of petty immigration dispositions is reported in Table M-IA; from 2000 on, it appears in Table M-2. All figures are for the year ending September 30.

31. Telephone conversation with Joanna Lydgate, July 9, 2010.

32. For every year through 2007 , the number of petty immigration dispositions shown in Table 5 considerably exceeds the number of $\$ 1325$ prosecutions shown in Table 4 . The explanation appears to be that the numbers in Table 4 are based on statistics reported by federal prosecutors around the country to the Department of Justice, and those statistics were previously incomplete; the offices of some United States Attorneys apparently failed to report some or all of their petty prosecutions under $\$ 1325$. Id.; Lydgate, supra note 2, at 2 n.5; Spencer S. Hsu, Immigration Prosecutions Hit New High, Wash. Post, June 2, 2008, at AI. 
Table 5. Petty immigration dispositions by magistrates, 1997-2009

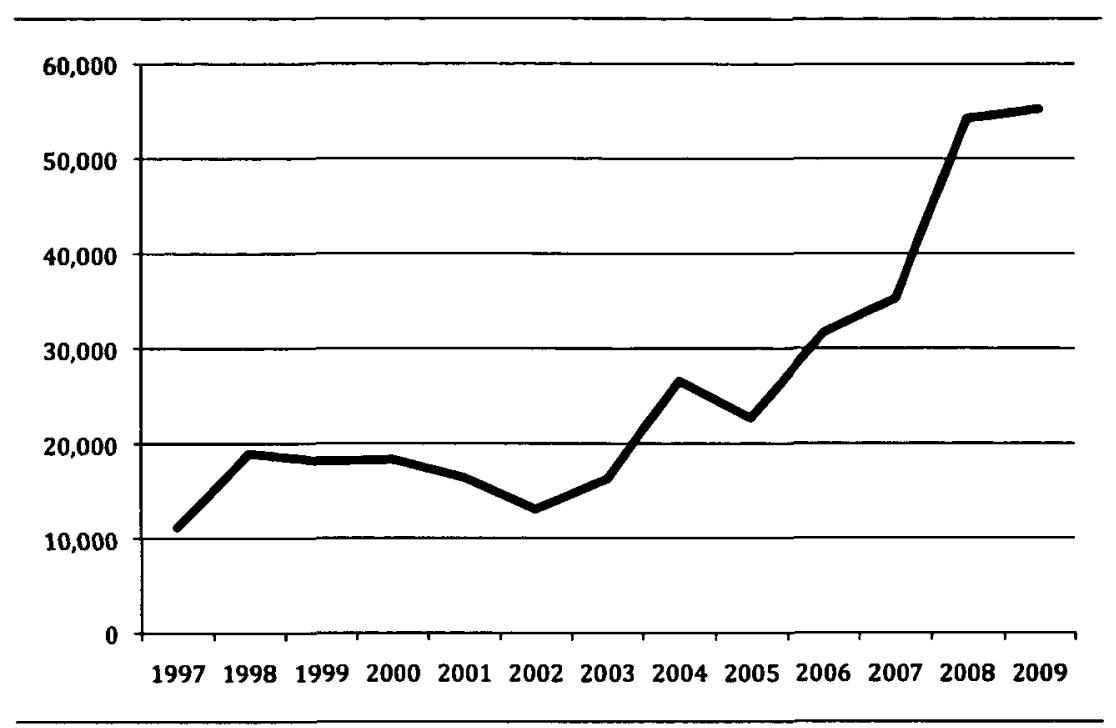

To deal with the large numbers of defendants charged under Operation Streamline, Border Patrol attorneys - who work for the Department of Homeland Security (DHS), not the Department of Justice-have been deputized in some jurisdictions, including Tucson and Del Rio, as Special Assistant United States Attorneys to prosecute these cases. As a practical matter, these attorneys continue to operate out of Border Patrol offices and may receive little oversight from the Justice Department or the local United States Attorney. ${ }^{33}$ Sometimes no government attorneys are involved at all; in some misdemeanor prosecutions, the United States is represented in court by Border Patrol agents. ${ }^{34}$ (As federal prosecution of immigration offenses and immigration enforcement overall have grown, so has the Border Parrol; it is now the federal government's largest armed enforcement agency. ${ }^{35}$ )

The sentences imposed under Operation Streamline tend to be relatively short. Although some defendants receive the statutory maximum of six months, many more are sentenced to time served. The average is roughly thirty days. ${ }^{36}$ For defendants convicted of illegal reentry after deportation,

33. See Lydgate, supra note 2, at I5; Eagly, supra note 8.

34. See Eagly, supra note 8.

35. See, e.g., Stumpf, supra note 6, at 388.

36. See Lydgate, supra note 2, at 12. 
Table 6. Defendants sentenced for illegal reentry, 1996-2009

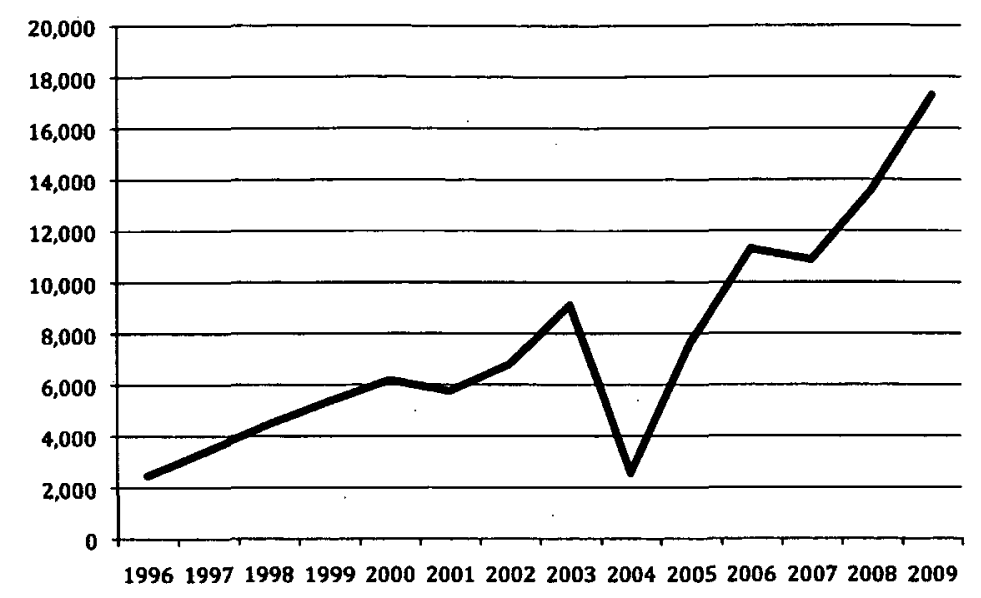

the average is significantly longer, twenty-one months. ${ }^{37}$ And the number of these cases has been growing dramatically, too. Table 4 records the number of cases charged under $\$ 1326$, but some of these cases were dismissed, resulted in acquittals, or ended consensually in pleas to violations of $\$ 1325$ or some other reduced charges. Table 6 shows the number of defendants actually sentenced for illegal entry each year from 1996 through 2009. ${ }^{38}$ The annual tally increases roughly eightfold over that period, with a temporary drop in 2004 .

37. The mean sentence for defendants sentenced under $\$ 2$ LI.2 of the United States Sentencing Guidelines for the 2009 fiscal year was 21.2 months. See United States Sentencing Commission, Sourcebook of Federal Sentencing Statistics, tbl. 50 (2009), www.ussc.gov/Data_and_Statistics/Annual_Reports_and_Sourcebooks/2009/Table5o.pdf. Section 2 Lr.2 of the guidelines applies not only to convictions obtained under 8 U.S.C. $\$ 1326$, the illegal reentry statute, but also to nonpetty convictions under 8 U.S.C. $\$ 1325$-i.e., to convictions under $\$ 1325$ for a second or subsequent offense. See United States Sentencing Commission, Federal Sentencing Guideline Manual \$2L2.I comm. (2009), www.ussc.gov/Guidelines/2009_guidelines/Manual/GL2009.pdf; id. app. C, amend. 38, www.ussc.gov/Guidelines/2009_guidelines/Manual/APPCVOLI.pdf. A case of the latter sort also will be chargeable, and probably will be charged, under $\$ 1326$, although it may ultimately be pleaded down to a violation of $\$ 1325$.

38. The data in Table 6 are drawn from the Sourcebook of Federal Sentencing Statistics, published annually by the United States Sentencing Commission since 1996 and available at www.ussc.gov/Data_and_Statistics/archives.cfm. The numbers are for years ending September 30. They are found in Table 45 of the 1996 volume and in Table 50 of 
Table 7. Immigration apprehensions, 1986-2008

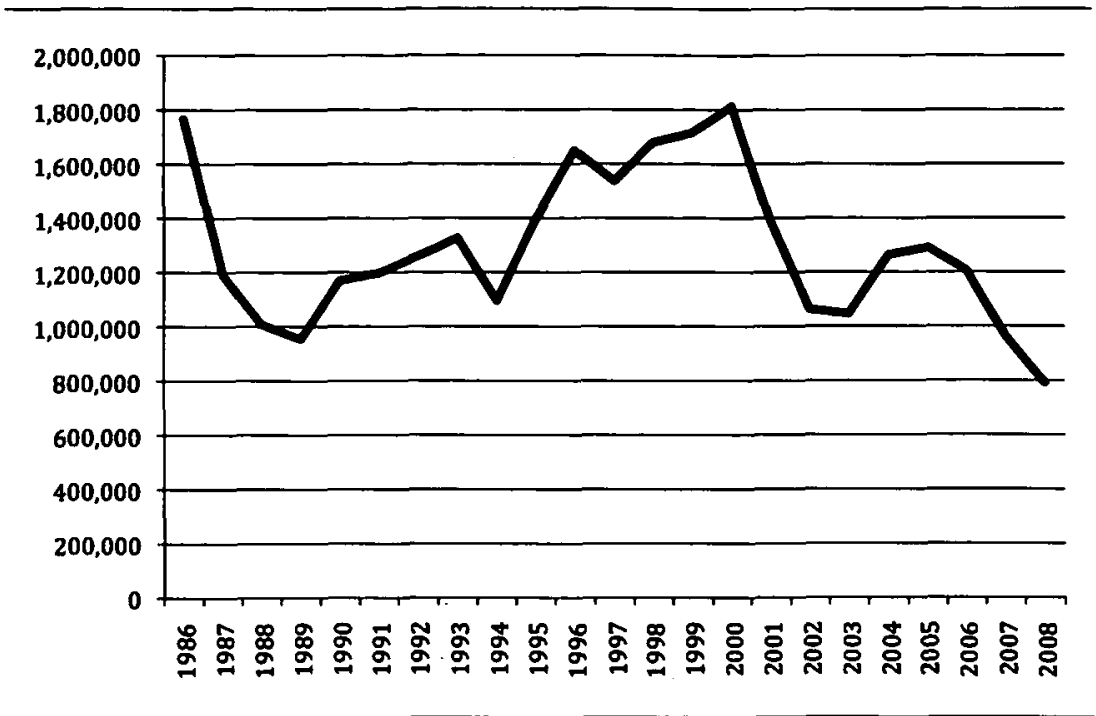

The bottom line is that criminal prosecutions for illegal entry into the United States have have grown vastly more common over the past decade and a half. Criminal prosecution of people caught entering the United States illegally used to be an insignificant portion of the overall business of federal prosecutors and federal courts; today it is a major part of what the federal criminal justice system does, and by one measure - cases filed-it is a majority of what the federal criminal justice system does.

Criminal prosecutions for immigration violations used to be a rarity in another respect, as well: few people caught entering the country illegally were charged criminally. Over the past quarter-century the number of undocumented aliens apprehended each year has bounced up and down, between a high of $1,800,000$ in 1986 and 2000 , and a low of 613,000 in 2009. The trend over the past decade has been one of steady and dramatic decline, interrupted by a two-year uptick in 2004 and 2005 . Table 7 shows the partern. ${ }^{39}$

the subsequent volumes. These tables also show the average sentence in illegal entry cases for each year; that number rises from 28.9 months in 1996 to 36 months in 2000 and then falls steadily to 21.2 months in 2009.

39. For Table 7 data, see Office of Immigration Statistics, U.S. Department of Homeland Security, 2009 Yearbook of Immigration Statistics, tbl. 33 (2010) [hereinafter 2009 Yearbook of Immigration Statistics], www.dhs.gov/files/statistics/publications/yearbook. shtm. The data are reported for the year ending September 30. 
Table 8. Immigration apprehensions resulting in prosecution, 1986-2008

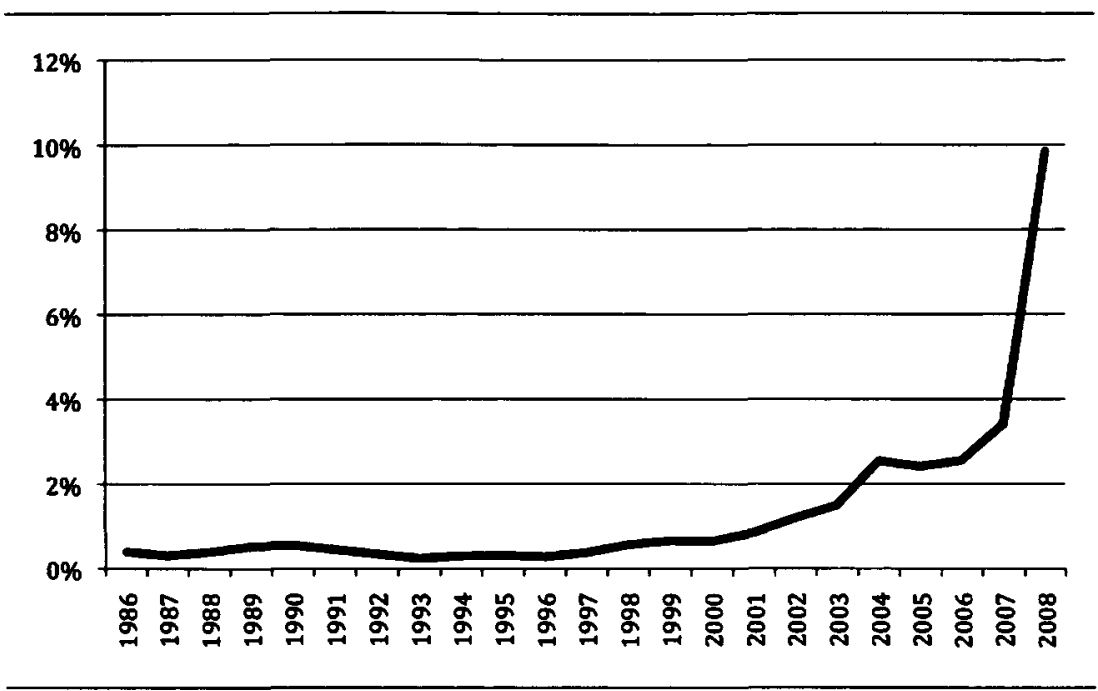

Over the same period of time, as we have seen, the number of criminal prosecutions for illegal entry has risen steadily and dramatically. Table 8 gives a sense of the result: the fraction of illegal entrants charged criminally has also risen steadily and dramatically. ${ }^{40}$

Despite Operation Streamline, most people caught crossing into the United States illegally are still not prosecuted. ${ }^{41}$ Partly that is because Operation Streamline has not been implemented everywhere along the southwest border: federal prosecutors in the Southern District of California have opted out of the program, choosing instead to prosecute only those undocumented border crossers with serious criminal histories or multiple prior illegal entries. ${ }^{42}$ And partly it is because Operation Streamlinealthough sometimes described as a "zero tolerance" program-does not in

40. Table 8 is constructed from the data in Tables 4 and 7. For each year, the total number of cases charged under 8 U.S.C. $\$ 1325$ and 1326 is divided by the number of apprehensions. The numbers in Table 8 for years through 2007, and particularly for the period from to 2004 to 2007 , are probably too low, and the jump in 2008 is probably not quite as steep as Table 8 suggests, because local federal prosecutors apparently underteported petty immigration prosecutions through 2007 . See supra note 32 and accompanying text.

4I. See Eagly, supra note 8.

42. See Joanna Lydgate, Chief Justice Earl Warren Institute on Race, Ethnicity \& Diversity, An Alternative to Operation Streamline: Border Enforcement in the Southern District of California (2010). 
practice result in the prosecution of everyone apprehended entering the country illegally. The Border Patrol routinely diverts children, parents travelling with childen, and individuals with serious health problems from the program. ${ }^{43}$ The same treatment may also sometimes be given to women, and to individuals who speak neither English nor Spanish. ${ }^{44}$ In addition, some jurisdictions cap the number of Operation Streamline prosecutions they will prosecute each day. ${ }^{45}$ This is particularly significant in the Tucson area, where upward of 240,000 undocumented migrants are apprehended annually, ${ }^{46}$ but the local federal district court has determined that, at present, it can process only seventy misdemeanor immigration cases each working day. ${ }^{47}$ There are calls to pump more money into Operation Streamline, though, ${ }^{48}$ and in particular to expand its scope in the Tucson area. ${ }^{49}$ And the trend, in any event, is clear: the fraction of illegal entrants criminally prosecuted used to be trivial; it is now appreciable and growing rapidly.

\section{B. Deportation as a Tool of Crime Control}

Just as criminal penalties used to be rare for immigration violations, immigration penalties, and in particular deportation, used to be rare for criminal activity. This, too, has changed. The practice of expelling noncitizens when they were convicted of crimes began in 1917, but it began slowly. For well over half a century, except in narrow circumstances, only convictions for crimes of "moral turpitude" could provide the basis for deportation, and not even those crimes would suffice if the sentence was imprisonment for a year or less, or if judge recommended against deportation at the time of sentencing, or if the defendant was later pardoned. ${ }^{50}$

43. See Lydgate, supra note 2, at 3 n.II.

44. See Chacón, Managing Migration, supra note 6, at 142 n.39.

45. See, e.g., Lydgate, supra note 2, at 4 n.15.

46. See 2009 Yearbook of Immigration Statistics, supra note 39, at tbl. 35. The Tucson sector annually accounts for roughly 40 percent of all border apprehensions nationwide. See id.

47. Email from Joanna Lydgate to author, July 16, 2010 (on file with author).

48. See Dylan Smith, McCain, Kyl Announce Border Security Plans, Tucson Sentinel, Apr. 19, 2010, www.tucsonsentinel.com/local/report/041910_mccain_kyl_border.

49. Jon Kyl \& John McCain, Gov't is Failing Border Residents, Florence (Ariz.) Reminder \& Blade-Tribune, July 8, 2010, trivalleycentral.com/articles/20ro/07/08/florence_ reminder_blade_tribune/top_stories/doc4c35019888d22220419477.txt. so. See, e.g., Kanstroom, supra note $\mathbf{I}$. 
Here is a window into how the matter was commonly viewed. In the mid-I920s, a man named Walter Klonis was ordered deported after he was twice convicted of burglary, and twice sentenced to a year in prison. Klonis had come to the United States from Poland when he was a child. The judge who had sentenced Klonis the second time hurriedly made a recommendation against deportation, but it was too late: the statute required the judicial recommendation to be made at the time of sentencing or within thirty days thereafter. The Second Circuit found itself without authority to block the deportation, but it urged that Klonis be pardoned so that he could stay in the United States. ${ }^{51}$ Writing for the court, Judge Learned Hand expressed strong discomfort with the whole idea of banishing immigrants because of their crimes:

However heinous his crimes, deportation is to him exile, a dreadful punishment, abandoned by the common consent of all civilized peoples. Such, indeed, it would be to any one, but to one already proved to be incapable of honest living, a helpless waif in a strange land, it will be utter destruction. That our reasonable efforts to rid ourselves of unassimilable immigrants should in execution be attended by such a cruel and barbarous result would be a national reproach. ${ }^{52}$

If a national reproach, it is now a reproach of very great proportions. In a series of statutes beginning in the 1980 , Congress significantly expanded the category of convictions that could provide the basis for deportation, it took away the power that sentencing judges previously had to block deportation by recommending against it, and it narrowed the circumstances in which administrators were formally authorized to forego deportation following a qualifying conviction. ${ }^{53}$ Last spring, the Supreme Court recognized that deportation "is now virtually inevitable for a vast number of noncitizens convicted of crimes"- so much so that a defendant's right

5I. United States ex rel. Klonis v. Davis, I3 F.2d 630 (1926).

52. Id. at 630-31.

53. See, e.g., Kanstroom, supra note I. Even in the absence of de jure statutory authority to waive deportation, however, the Executive Branch continued to assert and to exercise "prosecutorial discretion" in determining whether to seek removal of particular aliens. See Adam B. Cox \& Christina M. Rodriguez, The President and Immigration Law, ing Yale L.J. 458, 517-19 (2009); Shoba Sivaprasad Wadhia, The Role of Prosecutorial Discretion in Immigration Law, 9 Conn. Pub. Int. L.J. 243, 252-56 (2010). 
to the effective assistance of counsel in a criminal case can be violated if her lawyer fails to advise her about the likelihood that a guilty plea could get her expelled. ${ }^{54}$

For all intents and purposes, deportation is mandatory today whenever a noncitizen is convicted of a crime of "moral turpitude," or any narcotics offense other than possession of a very small amount of marijuana, or an "aggravated felony" - a category that has been progressively widened to include many offenses that would not commonly be considered "aggravated," and even some crimes that are not felonies. 55 Any of the following qualify as an aggravated felony, for example, if the defendant is sentenced to a year or more in prison, even if the sentence is suspended: any crime using force or the threat of force against another person, theft, receipt of stolen property, trafficking in fraudulent documents, fraud, deceit, perjury, certain forms of prostitution, commercial bribery, vehicle trafficking, certain gambling offenses, and sexual abuse of a minor. ${ }^{56}$ And conviction for an aggravated felony not only triggers mandatory deportation, it also triggers mandatory preventive detention while awaiting deportation (a matter to which I will return), and it bars return to the United States for life, unless special permission is given by the Secretary of Homeland Security. ${ }^{57}$

All of this legislation has had an effect. Deportations because of criminal convictions have increased markedly. Since 1996, deportation proceedings, to expel a noncitizen from the country, have been grouped together with exclusion proceedings, to bar a noncitizen from entering, and handled under a unitary proceeding called a "removal." 58 Over a

54. Padilla v. Kentucky, 130 S. Ct. 1473, 1478 (2010).

55. See Carachuri-Rosendo v. Holder, 130 S. Ct. 2577, 2580-81 (2010); Legomsky, supra note 3, at 483-86; Miller, supra note 3, at 632-35; Lea McDermid, Comment, Deportation is Different: Noncitizens and Ineffective Assistance of Counsel, 89 Cal. L. Rev. 74I, 756-62 (2001).

56. 8 U.S.C. $\$$ inor(a)(43). But not a misdemeanor conviction for a small amount of marijuana that could have been, but was not, charged as a felony because the defendant had a prior conviction. See Carachuri-Rosendo, 130 S. Ct. at 2589-90.

57. 8 U.S.C. $\$$ II82(a)(g)(A)(ii)-(iii), I226(c)(I); see Legomsky, supra note 3, at 483-84.

58. 8 U.S.C. $\$ 1229 \mathrm{a}(3)$; see, e.g., Chacón, A Diversion of Attention?, supra note 8, at I565 n.2. Historically, deportations outnumbered exclusions by roughly ro:I. Compare, e.g., Office of Immigration Statistics, U.S. Department of Homeland Security, 2004 Yearbook of Immigration Statistics, tbl. 44 (2005) [hereinafter 2004 Yearbook of Immigration Statistics], www.dhs.gov/files/statistics/publications/yearbook.shtm, with id. tbl. 46 . 
Table 9. Removals based on criminal convictions, 1981-2005

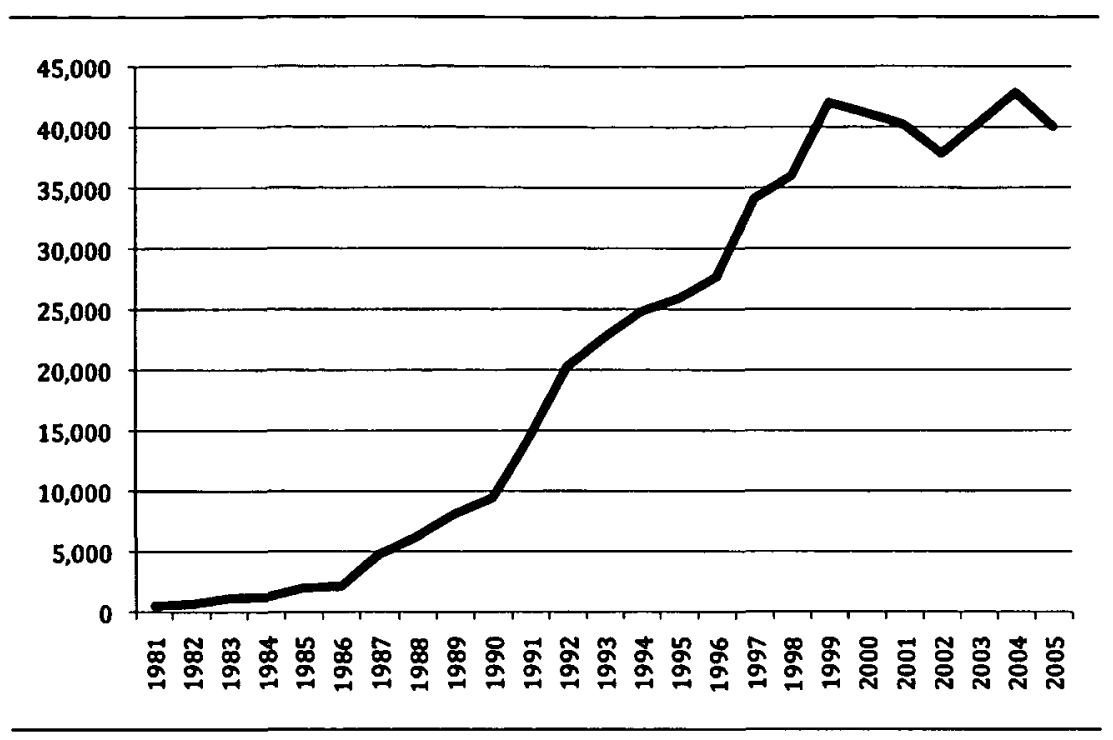

twenty-five-year period, from 198I through 2005, the number of noncitizens "removed" each year because of criminal convictions increased eightyfold - that is to say, by nearly two orders of magnitude-from just over 500 in 1981 to more than 40,000 in 2005 . The year-to-year growth is shown in Table $9 .{ }^{59}$

Table 9 understates the extent to which deportation has become a tool of crime control, because it does not include deportations for nominally noncriminal reasons that are in fact motivated by criminal convictions or suspicion of criminal activity. For the first fourteen years covered in Table 9, removals for reasons other than criminal conduct grew relatively slowly, so that by the mid-1990s a majority of removals were based on criminal convictions. Then removals for other reasons began to explode, and by 2005 they were again dwarfing removals based on criminal conduct. Table 10 shows the pattern.

It is likely that a significant number of the removals based on factors other than criminal conduct were in fact motivated by the criminal records

59. The data in Tables 9 and 10 for the years $198 \mathrm{I}-2044$ are taken from 2004 Yearbook, supra note 58 , tbls. $42,44,846$. The data for 2005 are from United States Department of Homeland Security, Office of Immigration Statistics, 2oos Yearbook of Immigration Statistics, tbl. 40 (2006). 
Table 10. All removals, 1981-2005

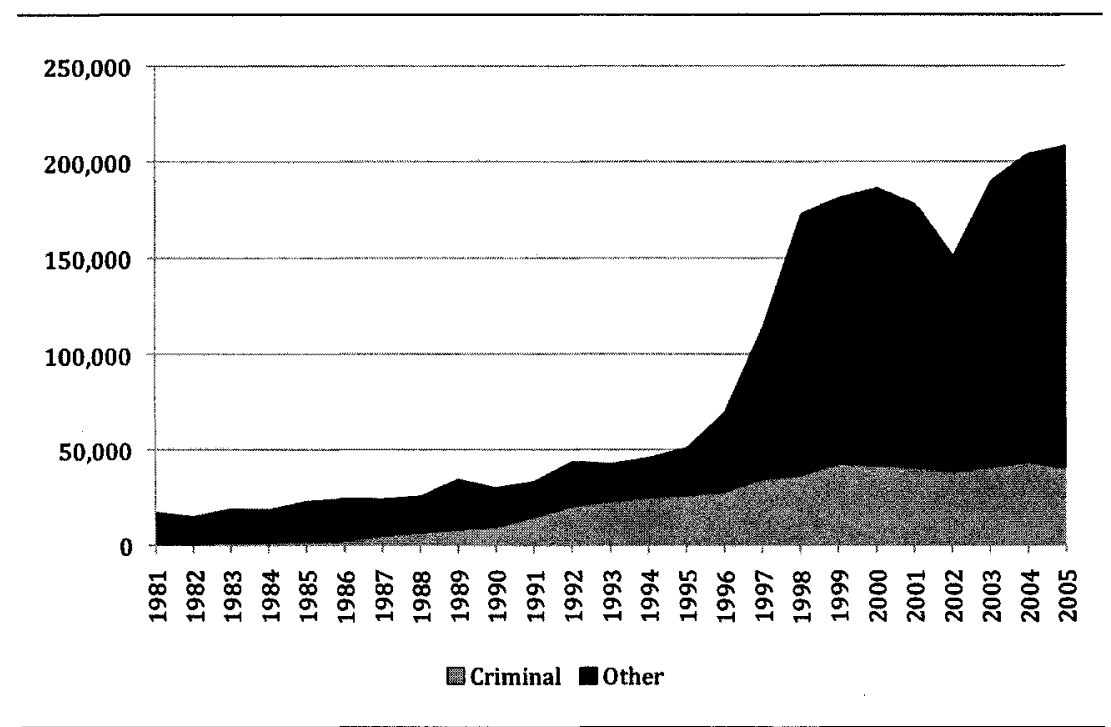

of the noncitizens involved or by suspicion that they were involved in criminal activity. The Department of Homeland Security itself noted, in reporting these numbers, that they reflected only "the legal basis for removal," and that " $[s]$ ome aliens who are criminals may be removed under a different administrative reason (or charge) for the convenience of the government." 60 In 2004, for example, when there were approximately 43 ,000 removals that were officially based on criminal conduct, there were roughly 46,000 noncitizens with criminal records who were removed on some other basis. ${ }^{61}$ In 2006, recognizing the artificiality of its legal categories, DHS stopped compiling and reporting separate data on the official bases for removals. The statistics that DHS did continue to keep indicate that by 2009 , the annual number of removals had swelled to slightly over 393,000 - more than double the figure for 2000 and more than ten times the figure for 1990-and that 128,000 of those proceedings either were formally based on criminal conduct or involved noncitzens with criminal records. $^{62}$

6o. See, e.g., 2004 Yearbook of Immigration Statistics, supra note 58, tbl. 42 note.

6r. See id. tbls. $42 \& 43$.

62. See 2009 Yearbook of Immigration Statistics, supra note 39, tbl. 38. In an August 20Io factsheet, ICE claimed that "criminal alien removals have increased . . . to $50 \%$ of the 
Even that figure of 128,000 likely excludes an appreciable number of removals motivated by suspicion of criminal activity, but not involving a criminal charge or a person with a criminal record. Since 2005 , for example, Immigration and Customs Enforcement (ICE) - currently the lead federal investigative agency for immigration enforcement ${ }^{63}$ - has worked with local law enforcement officials to arrest members and associates of violent street gangs who are in the country illegally, sometimes with an eye to prosecution but more often with an eye to deportation. Local police agencies are tyically responsible for determining who qualifies as a "member" or "associate" of a gang; no criminal record is required. Over the past five years, several thousand noncitizens without any criminal record may have been targeted for deportation through this program, which ICE calls Operation Community Shield. ${ }^{64}$ The mindset underlying Operation Community Shield-that immigration law can be a useful way to deal with dangerous individuals without taking on the burdens of a criminal

total aliens removed." Immigration and Customs Enforcernent, U.S. Department of Homeland Security, Setting the Record Straight 4, 6 (2010) [hereinafter Setting the Record Straight].

63. ICE is part of the Department of Homeland Security. When it created the DHS in 2002, Congress transferred and divided up responsibilities previously exercised by the Immigration and Naturalization Service (INS), within the Department of Justice. Most immigration enforcement responsibilities were given to ICE, but border administration was placed in Customs and Border Protection, another division of DHS. (Still another component of DHS, Citizenship and Immigration Services, took over many of the administrative functions previously performed by INS, including the granting of asylum, employment authorization, permanent resident status, and citizenship.) See Homeland Security Act of 2002, Pub. L. No. 107-296, 116 Stat. 2135 (2002). ICE is not merely a relocated branch of INS, though; it is a relocated and vastly expanded branch of INS. "Prior to September II, 200I, the INS had fewer than two thousand agents to enforce immigration laws in the interior of the United States. . . In 2010, ICE will have 20,000 employees." Chacón, A Diversion of Attention?, supra note 8, at 1572.

64. See Chacón, Whose Community Shield?, supra note 8, at 327-32, 345-48; Kirk Semple, Gang Activity Now a Focus for Immigration Agents, N.Y. Times, Dec. Io, 2010, at A23. ICE claims that Operation Community Shield has resulted in "over 6,000 criminal arrests and nearly 9,000 administrative immigration arrests," and that "nearly 6,000 of the arrested suspects had violent criminal histories." Immigration and Customs Enforcement, United States Department of Homeland Security, Targeting Violent Transnational Street Gangs, www.ice.gov/community-shield/. Not all of the gang members or gang associates targeted under Operation Community Shield are identified by local police agencies; some of the arrests under the program have resulted from operations carried out unilaterally by ICE. See Semple, supra. 
prosecution-is increasingly common. It forms an explicit part, for example, of the "pulling levers" strategy of violence reduction, which calls for "[d]elivering an explicit message that violence [will] not be tolerated" and then '[b]acking up that message by 'pulling every lever' legally available (i.e., applying appropriate sanctions from a varied menu of possible law enforcement actions) when violence occur[s]." ${ }^{65}$ We will return later to Operation Community Shield, "pulling levers," and the broader mindset that they exemplify. For now, the important point is that the use of immigration law as a tool of crime control has probably increased even more sharply than deportation statistics suggest.

\section{The Changing Character of Immigration Proceedings}

In addition to the dramatic rise in the criminal prosecution of immigration offenses and the equally dramatic increase in the use of the immigration system as a tool of crime control, there is a third respect in which the boundaries between the immigration system and the criminal justice system have blurred. As several scholars of immigration law have pointed out, immigration proceedings themselves have taken on a criminal justice cast. ${ }^{66}$ Partly this is because immigration enforcement has made growing use of the tools and techniques of criminal law enforcement, as the Border Patrol has expanded ${ }^{67}$ and-a matter to be discussed below-local law enforcement agencies have increased their involvement in immigration enforcement. Partly it is because negotiated settlements that include cooperation agreements, long a staple of criminal proceedings, have become more common in immigration proceedings, especially since the attacks of September II, 200r. ${ }^{68}$ But mostly it is because of the growth in immigration detentions. Probably nothing distinguishes criminal and civil

65. National Institute of Justice, U.S. Department of Justice, Reducing Gun Violence: The Boston Gun Project's Operation Ceasefire 2 (2001). On using the "lever" of deportation, see, e.g., David M. Kennedy, Anthony A. Braga, \& Anne M. Piehl, Designing and Implementing Operation Ceasefire, in id. at 5, 34.

66. See, e.g., Legomsky, supra note 3, at 489-500; Stumpf, supra note 6, at 386-92.

67. See supra note 35 and accompanying text.

68. See Legomsky, supra note 3, at 494-95; Nora Demleitner, Immigration Threats and Rewards: Effective Law Enforcement Tools in the "War" on Terrorism, sI Emory L.J. 1059, 1078-82 (2002). Negotiated dispositions without cooperation agreements have long been a staple of immigration proceedings, much as they are in criminal cases. The immigration equivalent to the negotiated guilty plea has been the "voluntary departure," 
Table 11. Average daily population in immigration detention, 1994-2009

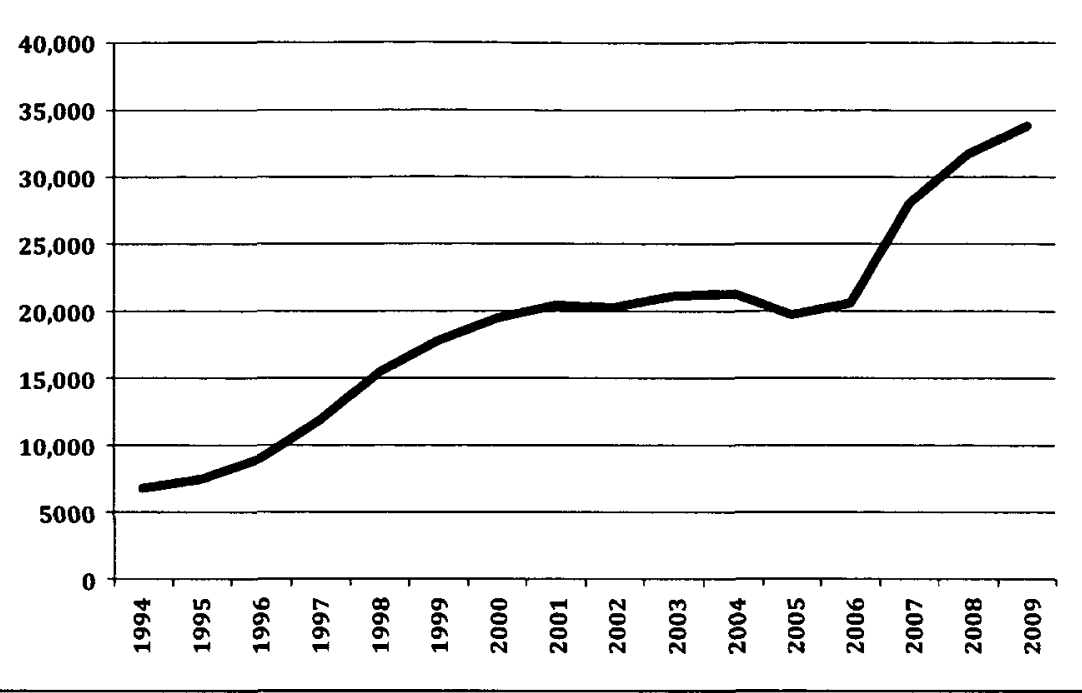

proceedings more sharply than the threat of incarceration, not only at the end of the process but often while the process is ongoing. Jailing people the government was trying to deport used to be unusual, but it has become commonplace. And as deportations have soared, a vast network of immigration detention facilities has emerged-a kind of parallel prison system, operating alongside and in conjunction with the network of facilities for criminal detention and punishment.

Table 11 shows the average daily population held in immigration detention from 1994 through 2009 . Over that fifteen-year period, the immigration detainee population has roughly quintupled in size, from about 6,800 in 1994 to just over 33,800 in $2009 .^{69}$

negotiated as an informal alternative to a judicial order of removal. See, e.g., Eagly, supra note 8.

69. The numbers in Table 11 come from Alison Siskin, Congressional Research Service, Immigration-Related Detention: Current Legislative Issues I2 (2004) for the years 1994-2002, www.fas.org/irp/crs/RL 32369.pdf; Alison Siskin, Congressional Reseach Service, Health Care for Noncitizens in Immigration Detention 26 (2008) for the years 2003-2006, www.policyarchive.org/handle/10207/bitstreams/18888.pdf; and Immigration and Customs Enforcement, U.S. Department of Homeland Security, Average Daily Population (ADP) for Fiscal Year 2009 (spreadsheet prepared pursuant to FOIA request, Oct. 2009) for the years 
Immigration and Customs Enforcement now "operates the largest detention system in the country." of more than 300 facilities: seven "Service Processing Centers . . . owned by ICE and operated by the private sector; seven dedicated Contract Detention Facilities . . . owned and operated by the private sector; . . . seven dedicated county jail facilities, with which ICE maintains intergovernmental agency service agreements," and-holding about half of all immigration detainees-roughly 240 "non-dedicated or shared-use country jails," also operated under interagency agreements. ${ }^{71}$ The heavy reliance on privately managed facilities is a long-standing feature of immigration detention. The first private prisons in the United States, which began operating in 1984, were immigration detention centers, ${ }^{72}$ and as prison populations decline, private prison operators increasingly see immigration detention as an important source of revenue. ${ }^{73}$

The total number of people detained each year in immigration facilities is much larger than Table 11 suggests, because most, but not all, detainees are held for relatively short periods of time. Roughly 380,000 aliens, for example, were detained for part or all of fiscal year $2008 .^{74}$ The average length of detention is thirty days, but there is wide variation. ${ }^{75}$ A quarter of all detainees are released within a day; ${ }^{76}$ some are held for months or even years. $^{77}$

2007-2009. The reports from the Congressional Research Service rely on data published by the INS and the DHS.

70. Dora Schriro, U.S. Department of Homeland Security, Immigration Detention Overview and Recommendations 6 (2009), http://www.ice.gov/doclib/about/offices/odpp/ pdf/ice-detention-rpt.pdf.

7.. Id. at Io.

72. See Mark Dow, American Gulag: Inside U.S. Immigration Prisons 97 (2004).

73. See, e.g., Anil Kalhan, Rethinking Immigration Detention, no Colum. L. Rev. Sidebar 42, 57 \& n.IOI (2010); Meredith Kolodner, Immigration Enforcement to Benefit Detention Companies, N.Y. Times, Jul. 19, 2006, at Cr; Laura Sullivan, Prison Economics Help Drive Ariz. Immigration Law, NPR News Investigations, Oct. 28, 2010, www.npr.org/ templates/story/story.php?storyld=13083374t.

74. See Schriro, supra note 70 , at 6.

75. See id.

76. See id.

77. See Donald Kerwin \& Serena Yi-Yang Lin, Migration Policy Inst., Immigrant Detention: Can ICE Meet Its Legal Imperatives and Case Management Responsibilities? 17-18 (2009); Kalhan, supra note 73, at $49 \&$ n. 56 . 
As immigration detention grows more commonplace, it brings with it other accountrements of criminal proceedings, such as electronic monitoring ankle bracelets. ICE is currently experimenting with the use of ankle bracelets, along with telephone reporting and "community supervision," as an "alternative to detention" for low-risk aliens applying for residency or facing deportation proceedings. The pilot program, operated through a private contractor, is currently running in eight cities; ICE hopes to expand it to 165 cities and more than 27,000 aliens by $2014 .^{78}$

Some of the expansion of the immigration detention system has been fueled by new laws mandating the detention of certain aliens subject to deportation, 79 and especially the ballooning category of "aggravated felonies"-which, as we have seen, includes many crimes that are not in any meaningful sense "aggravated," as well as some that are not even felonies. ${ }^{80}$ By statute, any alien convicted of an aggravated felony is subject not only to mandatory deportation but also to mandatory detention pending deportation. ${ }^{81}$ But a great many aliens detained in the immigration detention system have not committed aggravated felonies and are not subject to mandatory detention. This was famously (or notoriously) the case in the wake of September II, 200I: the Department of Justice acknowledged using immigration detention to hold foreigners suspected of participating in terrorism or associating with terrorists. ${ }^{82}$ More recently, an outside review of January 25, 2009, detention data-released pursuant to a Freedom of Information Act request-concluded that 58 percent of the aliens detained on that date had no criminal record. ${ }^{83}$ A subsequent in-house report prepared by ICE revealed that, of the aliens held on September I, 2009, 34 percent were not subject to mandatory detention and 49 percent were not felons; only iI percent had commited violent offenses. ${ }^{84}$ Roughly a year

78. See Sarah Phelan, Who Profits from ICE's Electronic Monitoring Anklets?, S.F. Bay Guardian Online, Mar. I6, 2010, www.bestofthebay.com/politics/2010/03/16/whoprofits-ices-electronic-monitoring-anklets-o.

79. See Kalhan, supra note 73, at 45-46.

80. See supra text accompanying notes $55-57$.

8I. See 8 U.S.C. $\$$ I226(c)(I).

82. See, e.g., Harry Litman, Pretextual Prosecution, 92 Geo. L.J. II35, II36-37, II46-47, II67-68 (2004).

83. Kerwin \& Lin, supra note 77 , at $1-2$.

84. Schriro, supra note 70 , at 2. 
later, ICE reported that 57 percent of aliens in detention had criminal records. $^{85}$

The immigration detention system has long been criticized for its opacity and its lack of accountability. ${ }^{86}$ There has been a troubling tendency for detainees to get lost in the system or to be moved far from their families, their friends, and their attorneys, often for what appear to be capricious or retaliatory reasons. ${ }^{87}$ There has been a scandalous pattern of deaths in custody and, relatedly, a systemic failure to provide detainees with access to adequate medical care. ${ }^{88}$ The Obama administration has pledged to improve immigration detention and has already taken some significant steps, including the creation of an online system for locating detainees. ${ }^{89}$ But there are grounds for skepticism about how far the reforms will go, given the demands placed on the system, the resources it has been provided, an entrenched organizational culture of secrecy, and the political context within which the system operates. ${ }^{90}$

\section{Immigration Enforcement by Local Police}

In addition to maintaining separate adjudicatory systems and separate penalty regimes - prison for crimes, deportation for immigration violationscriminal justice and immigration enforcement used to have entirely separate front-line officials. Enforcement law was enforced by federal immigration officials, not by police officers. Local police departments stayed away from immigration enforcement not only because it was understood to be civil rather than criminal, and not only because it was understood to be a federal rather than a local responsibility, but because police departments wanted the trust and cooperation of immigrants--including immigrants worried about

85. Setring the Record Straight, supra note 62, at 4, 6 .

86. See, e.g., Dow, supra note 72, at II; Kalhan, supra note 73, at 47-48.

87. See, e.g., Dow, supra note 72 , at $96,114,181,253$; Kalhan, supra note 73 , at 48 \& n.46.

88. See, e.g., Kalhan, supra note 73 , at 47.

89. Immigration and Customs Enforcement, U.S. Department of Homeland Security, ICE Announces Launch of Online Detainee Locator System (Jul. 23, 2010), www.ice.gov/ news/releases/1007/100723washingtondc.htm.

90. See Dow, supra note 72, at 13, 86, 90, 283, 293; Kerwin \& Lin, supra note 77; Kalhan, supra note 73 , at $56-58$. 
their legal status. Many police departments still maintain that policy, but a large and growing number of them do not. ${ }^{91}$

Unlike the rise in immigration-related prosecutions, the increase in crime-related deportations, and the expansion of the immigration detention system, all of which started in the 1990s, the participation of local police in immigration enforcement began after the terrorist attacks of September II, 2001. In the wake of those attacks, the Department of Justice and later the Department of Homeland Security launched a series of programs aimed at enlisting local law enforcement agencies as partners in the enforcement of immigration laws and, conversely, allowing the police to use immigration law as a tool of crime control. ${ }^{92}$ One of those programs, discussed earlier in this paper, is Operation Community Shield, which since 2005 has facilitated some I5,000 arrests of aliens identified by local law enforcement agencies as being members or "associates" of street gangs. ${ }^{93}$ Operation Community Shield is part of what ICE calls "ACCESS," for Agreements of Cooperation in Communities to Enhance Safety and Security. ${ }^{94}$ That "umbrella of services and programs" 95 also includes cross-designation of state and local law enforcement officers to enforce federal immigration laws pursuant to memoranda of understanding authorized by $\$ 287(\mathrm{~g})$ of the Immigration and Naturalization Act, a provision added by the Illegal Immigration Reform and Immigrant Responsibility Act of $1996 .^{96}$ Until September II, 2001, no local

9I. See Debra A. Hoffmaster et al., Police Executive Research Forum, Police and Immigration: How Chiefs Are Leading Their Communities Through the Challenges (20II); Hubert Williams, Foreword, in Anita Khashu, Police Foundation, The Role of Local Police: Striking a Balance Between Immigration Enforcement and Civil Liberties, viii (2009); Julia Preston, Police Chiefs Wary of Immigration Role, N.Y. Times, Mar. 4, 20II, at AI7.

92. See Chacón, Managing Migration, supra note 6; Chacón, Whose Community Shield?, supra note 8; Miller, supra note 8, at 9I-93; Michael J. Wishnie, State and Local Police Enforcement of Immigration Laws, 6 U. Pa. J. Const. L. 1084, 1084-88 (2004).

93. See supra notes $64-65$ and accompanying text.

94. Office of State \& Local Cooperation, U.S. Department of Homeland Security, ACCESS-Agreements of Cooperation in Communities to Enhance Safety and Security [hereinafter ACCESS], www.ice.gov/access/; see also Chacón, A Diversion of Attention?, supra note 8 , at $1582 \rightarrow 95$.

95. ACCESS, supra note 94.

96. Pub. L. No. 104-208, div. C, $\$ 133$, I10 Stat. 3009- $546,-563 \&-564$ (codified as amended at 8 U.S.C. $\$ 1357(\mathrm{~g})$ ); see also, e.g., Chacón, A Diversion of Attention?, supra note 8 , at $1582-86$. 
or state law enforcement agency elected to enter into such a so-called "287(g)" agreement. ${ }^{97}$ By August 2010, ICE had entered into agreements with seventy-two local law enforcement agencies in twenty-six states, had certified more than I,190 state and local officers to enforce immigration law, and credited the $287(\mathrm{~g})$ program with "identifying more than 173,000 potentially removable aliens." 98

A newer and more ambitious program, Secure Communities, aims to have fingerprints taken from all arrested persons nationwide checked against DHS records (as well as FBI databases), so that ICE can, if it chooses, initiate immigration enforcement proceedings against any arrestee determined to be in the country illegally. ${ }^{99}$ ICE began implementation of the program in 2008 and hopes to have "nationwide coverage by $2013^{\prime \prime} ;{ }^{100}$ as of March 2011, it was operating in 1,265 jurisdictions in forty-two states. ${ }^{101}$ Although ICE describes Secure Communities as part of its efforts to "partner[] with federal, state, tribal, and local law enforcement ... to identify and remove criminal aliens," 102 the program is not part of ACCESS and, at least nominally, operates through agreements with states rather than with local law enforcement agencies. Partly because of inconsistent statements from

97. Khashu, The Role of Local Police, supra note 9I, at 5.

98. Office of State \& Local Cooperation, U.S. Department of Homeland Security, Delegation of Immigration Authority, Section $287(\mathrm{~g})$, Immigration and Naturalization Act (online factsheet), www.ice.gov/news/library/factsheets/287g.htm.

99. Immigration and Customs Enforcement, U.S. Department of Homeland Security, Secure Communities: A Modernized Approach to Identifying and Removing Criminal Aliens (2010) [hereinafter Secure Communities], www.ice.gov/doclib/secure-communities/ $\mathrm{pdf} / \mathrm{sc}$-brochure.pdf. Secure Communities is operated jointly by the DHS and the Department of Justice. Id. Although ICE describes it as a program focused squarely on removal, id., some local law enforcement agencies apparently see it as a way to incarcerate criminal aliens. See, e.g., Tess Townsend, "Secure Communities" Raises Questions, Bay Citizen, Aug. 18, 2010, www.baycitizen.org/immigration/story/homeland-securityprogram-deporting-bay/ (quoting Curtis Hill, president of the California state Sheriffs' Association, praising Secure Communities for "utiliz[ing] federal resources to get these folks back to prison").

10o. Office of State \& Local Cooperation, U.S. Department of Homeland Security, Secure Communities Fact Sheet (2009), http://www.ice.gov/doclib/foia/secure_communities/ securecommunitiespresentations.pdf.

Ior. Office of State \& Local Cooperation, U.S. Department of Homeland Security, Activated Jurisdictions, www.ice.gov/secure_communities/.

102. Secure Communities, supra note 99. 
the Department of Homeland Security, there has been a great deal of confusion about whether states and localities can opt of the program. ${ }^{103}$ From October 2008 through June 2010, Secure Communities resulted in 46,929 deportations. ${ }^{104}$ ICE claims that the program focuses on "dangerous criminals," 105 but 79 percent of the aliens deported through June 2010 had no criminal convictions or had been arrested for relatively low-level offenses. ${ }^{106}$

Not all of the involvement of local police in immigration enforcement has been driven by federal encouragement; some, in fact, has proceeded in the face of federal opposition. The most notorious example is Arizona's effort to require all of its police officers to run an immigration check anytime they stop someone they have "reasonable suspicion" is in the country illegally. After the Justice Department filed suit, a federal district judge

I03. Compare, e.g., Napolitano Confirms Secure Communities Opt-Out Process, Deportation Nation, Sept. 17, 2010, www.deportationnation.org/2010/o9/napolitanoconfirms-secure-communities-opt-out-process/, with Julia Preston, States Resisting Program Central to Obama's Immigration Strategy, N.Y. Times, May 6, 20II, at Ar8 (noting that DHS Secretary Janet Napolitano "has said that Secure Communities is mandatory"). There also has been confusion about whether a local agency can opt out except by refusing to share fingerprints with the federal criminal justice system-see Confusion Over Secure Communities, N.Y. Times, Oct. 5, 2010, at A26 - and about whether a local agency can opt out over the objection of the state in which it is located. See Kirk Semple, Program to Have Police Spot Illegal Immigrants Is Mired in Confusion, N.Y. Times, Nov. 10, 2010, at A23; Gene Davis, Unsure on Secure Communities?, Denver Daily News, Sept. 7, 2010; Samantha Bell, SF Sheriff Tries to Opt Out of Secure Communities Program, Again, SF Appeal, Sept. I, 20ro, sfappeal.com/ news/2010/og/post-I.php; Sarah Phelan, ICE Suggests SF Secure-Comm Opt-Out Possible, S.F. Bay Guardian, Sept. I, 2010, www.sfbg.com/politics/2010/og/o1/ice-suggests-sf-securecomm-opt-out-possible. It is also unclear whether localities can join the program without a state-level agreement. See, e.g., Michael Levenson, Opponents Blast Patrick on Immigration, Boston Globe, Sept. 24, 2010, at 4; Renée Feltz, Rapid Spread of Secure Communities May Ease Up, Deportation Nation, Sept. I4, 2010, www.deportationnation.org/2010/og/rapidspread-of-secure-communities-may-ease-up/.

104. See Center for Constitutional Rights, National Day Laborers' Organizing Network \& Kathryn O. Greenberg Immigration Justice Clinic, Briefing Guide to "Secure Communities," 2 n.7 (2010) [hereinafter Briefing Guide to "Secure Communities"], http://www.cardozo.yu. edu/uploadedFiles/Cardozo/Profiles/immigrationlaw-74I/NDLON_FOIA_Briefing\%2oguide. final.pdf.

ro5. Secure Communities, supra note 99; see also, e.g., Setting the Record Straight, supra note 62.

ro6. Briefing Guide to "Secure Communities," supra note 104, at $2 \&$ n.7. 
enjoined that program on preemption grounds; Arizona has appealed the order. $^{107}$

Immigration enforcement is still understood as first and foremost a federal responsibility, and many if not most local police departments remain reluctant to share that responsibility. But the line dividing the work of local policing from the work of federal immigration authorities, which used to be sharp, is now much hazier. This is yet one more way in which the boundary between criminal justice and immigration enforcement is becoming far less distinct.

\section{UNDERSTANDING CRIMMIGRATION}

What should we make of the blurred boundary between criminal justice and immigration enforcement? What is driving this phenomenon, and what challenges does it present? I will argue below that crimmigration is in part a manifestation of a larger phenomenon, the rise of what I will call "ad hoc instrumentalism" in setting the limits of criminal law. Before making that argument, though, I want to explain why crimmigration cannot be fully understood in more straightforward terms: why it will not suffice to view crimmigration as simply a pragmatic response to facts on the ground; or as nativism plain and simple; or as merely another example of the relentless expansion of the rules and rhetoric of criminal law.

\section{A. Immigrants and Crime}

Let us start with pragmatism. Whatever else explains the developments examined in the first part of this paper, they cannot be understood as a response to the rising problem of crime committed by noncitizens. They cannot be understood in that way because there is no such problem. Over

107. United States v. Arizona, 703 F. Supp. 2d 980 (D. Ariz. 2010), aff'd, 641 F.3d 339 (9th Cir.), cert. granted, 132 S. Ct. 845 (2011). Other provisions of the Arizona law, also enjoined by the district court, make it a state crime for any noncitizen to seek work in Arizona or to fail to carry an alien registration document, and require the police to check the immigrations status of all arrested persons before they are released. See United States v. Arizona, 703 F. Supp. $2 \mathrm{~d}$ at 987 . Regarding the involvement of the private prison industry in the drafting and passage of the Arizona law, see Sullivan, supra note 73. 
Table 12. Incarceration rates of males aged 18-39, 2000

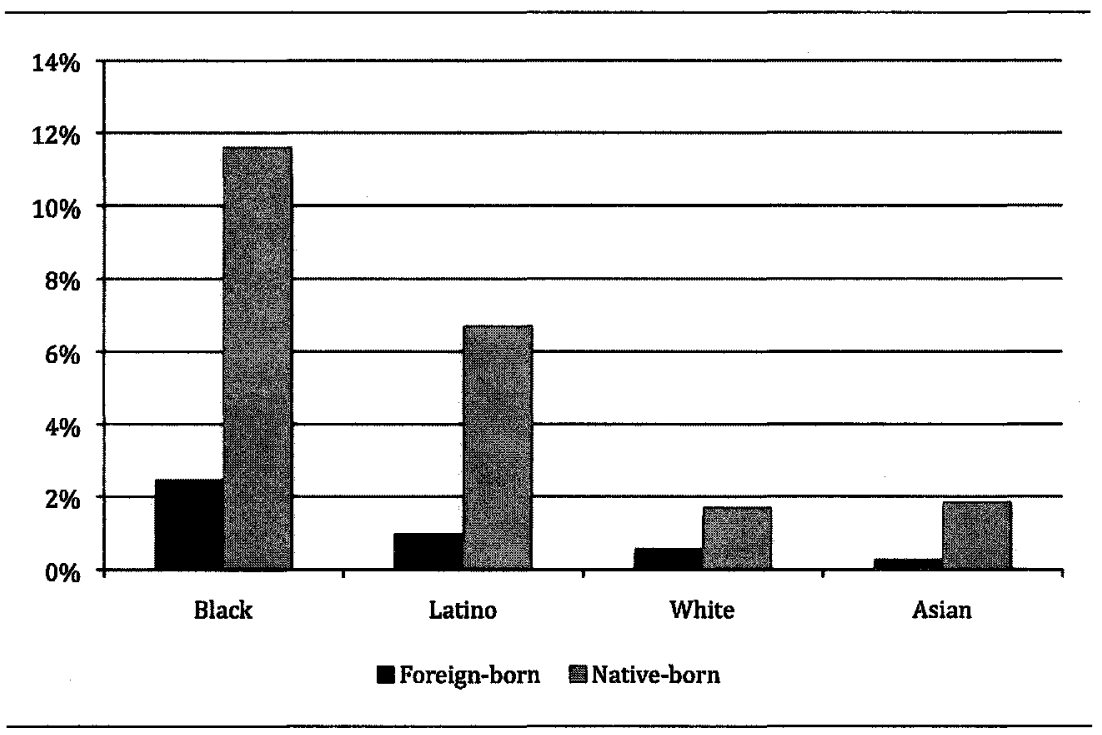

the past two decades, crime rates have fallen across the country, including in border states. ${ }^{108}$ As we have seen, border apprehensions have fallen dramatically, too. ${ }^{109}$

Moreover, there is no evidence that immigrants, documented or undocumented, are responsible for a disproportionate share of crime, and quite a bit of evidence in the other direction. Some of that evidence has to do with what we know about crime rates among immigrants and native-born Americans, based on who winds up in jails and prisons. And what those numbers suggest is that, across virtually every demographic group, immigrants are much more law-abiding than native-born Americans. Table 12 compares the incarceration rates of several subpopulations of immigrant

I08. See, e.g., Franklin E. Zimring, The Great American Crime Decline (2007); Rubén G. Rumbaut, Appendix D, Undocumented Immigration and Rates of Crime and Imprisonment: Popular Myths and Empirical Realities, in Khashu, The Role of Local Police, supra note 9I, at II9, 124-25 (2009); Randal C. Archibold, In Border Violence, Perception is Greater Than Crime Statistics, N.Y. Times, June 20, 2010, at Ar8; Charlie Savage, Crime Rates Fell in 'o9 Despite Economy, F.B.I. Says, N.Y. Times, May 25, 20I0, at AIs; Barry Krisberg, Berkeley Center for Criminal Justice, Where Is the Fire? Immigrants and Crime in California (20IO).

I09. See supra text accompanying note 39. 
and native-born males aged I8-39, the age and gender cohort most prone to criminal offending. ${ }^{110}$

There are some problems with comparisons of this kind. They do not take into account the fact that native-born Americans have been here longer, so they are, in effect, over-sampled in the prison population relative to immigrants. And the available statistics lump undocumented immigrants together with those who entered the country legally, so they could, in theory, hide higher rates of offending among undocumented immigrants. On the other hand, the incarceration rate among immigrants as a whole is likely overstated in these studies, because they rely on population statistics drawn from the decennial census, and those figures inevirably undercount immigrants, especially those here illegally. ${ }^{11}$

One way around these problems is to examine crime rates in places where we know there are large numbers of undocumented immigrants. Table 13 compares the rates of violent crimes in four cities along the southwest border-Brownsville, El Paso, Laredo, and San Diego_-with all other American cities with populations greater than I0o,ooo. ${ }^{112}$ Crime rates in the border cities are relatively low. The pattern is particularly noteworthy because the Mexican municipalities just across the border from Brownsville, El Paso, Laredo, and San Diego-Matamoros, Juarez, Nuevo Laredo, and Tijuana, respectively-are notoriously crime-ridden. ${ }^{113}$

Table 13 groups together the violent offenses included in the Uniform Crime Reports collected by the FBI (homicide, forcible rape, robbery, and aggravated assault), but the pattern is the same for property offenses. As Table 14 illustrates the pattern is also the same for homicide rates considered

IIO. The data are taken from Rumbaut, supra note 108, at 127. Long-term historical data show roughly the same pattern. See Carolyn Moehling \& Anne Morrison Piehl, Immigration, Crime, and Incarceration in Early Twentieth-Century America, 46 Demography 739 (2009).

III. See, e.g., Panel on Correlation Bias and Coverage Measurement in the 2010 Decennial Census, National Research Council, Coverage Measurement in the 2010 Census 44, 45 , II2, II4, 117 (2009).

I12. The numbers in Tables 13 and 14 are from the Uniform Crime Reports collected by the FBI for 2009 .

113. See, e.g., Tim Padgett, The "Dangerous" Border: Actually One of America's Safest Places, Time, July 30, 2010, www.time.com/time/nation/article/o,8599,2007474,00.html; Dennis Wagner, Violence Is Not Up on Arizona Border Despite Mexican Drug War, Ariz. Republic, May 2, 2010, www.azcentral.com/news/articles/2010/05/02/20100502arizona-border-violencemexico.html?source=nletter-news. 
192 | NeW CRIMINAL LAW REVIEW | VOL. 15 | NO. 2 | SPRING 2012

Table 13. Major U.S. cities ranked by violent crime per 100,000 inhabitants, 2009

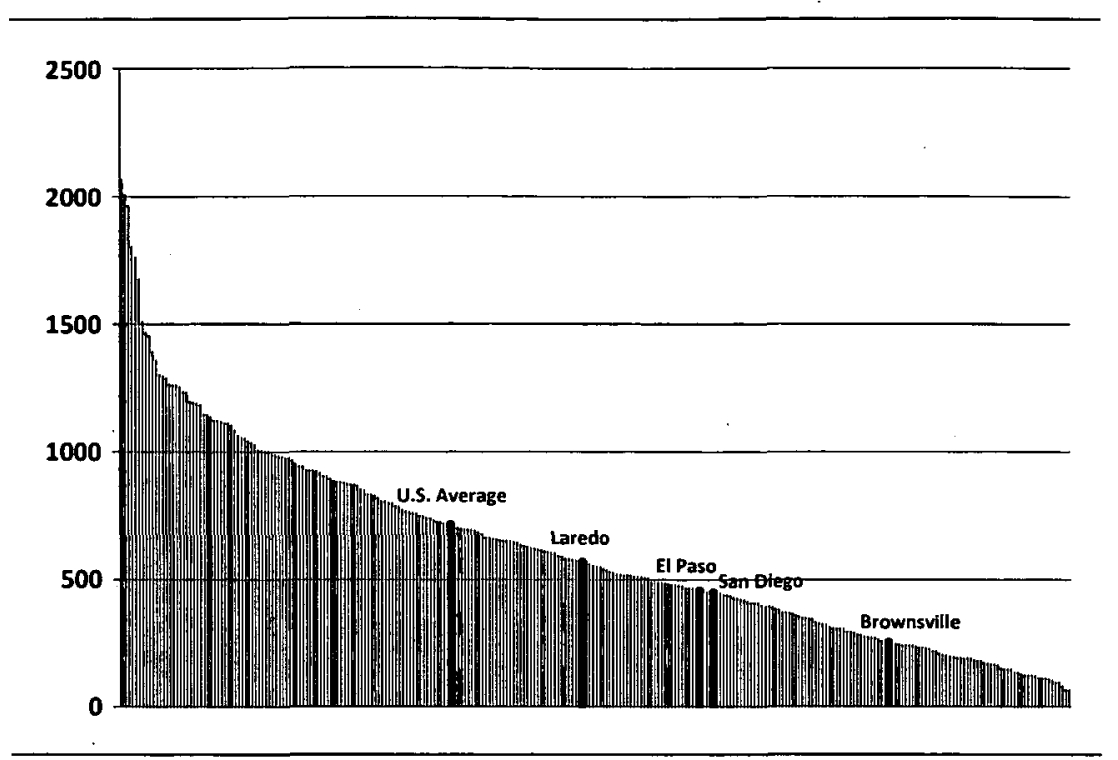

Table 14. Major U.S. cities ranked by homicides per 100,000 inhabitants, 2009

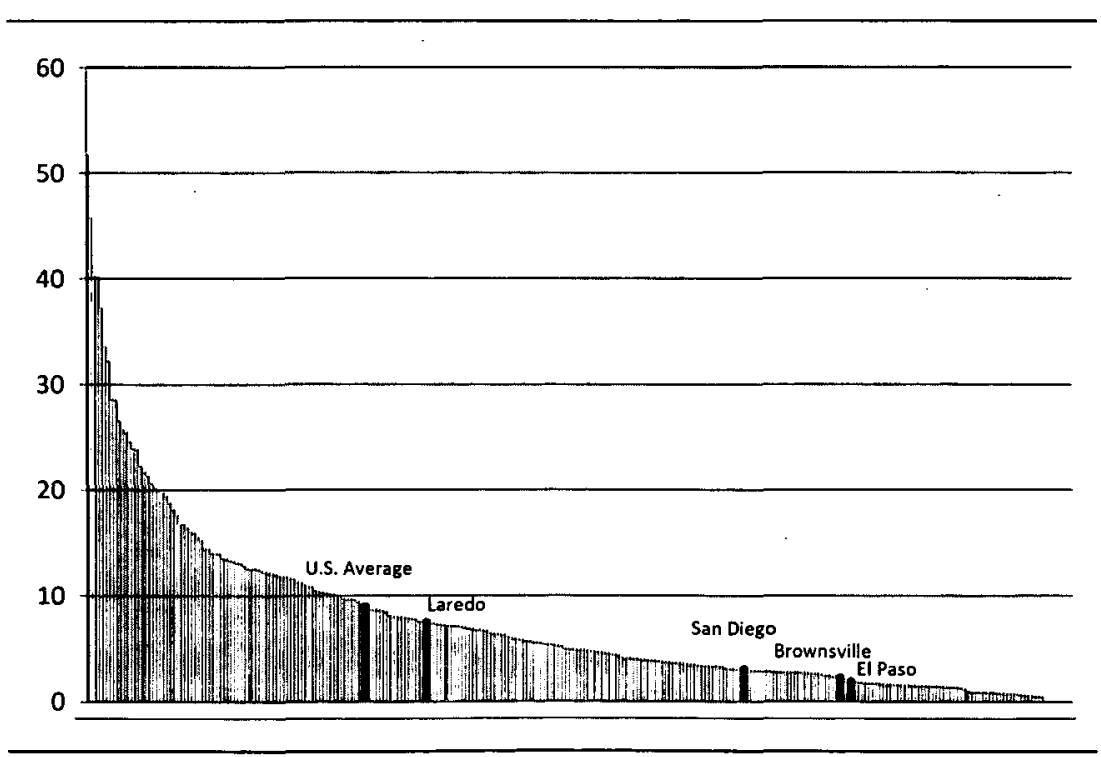


Table 15. Foreign-born percentage of U.S. population, 1850-2008

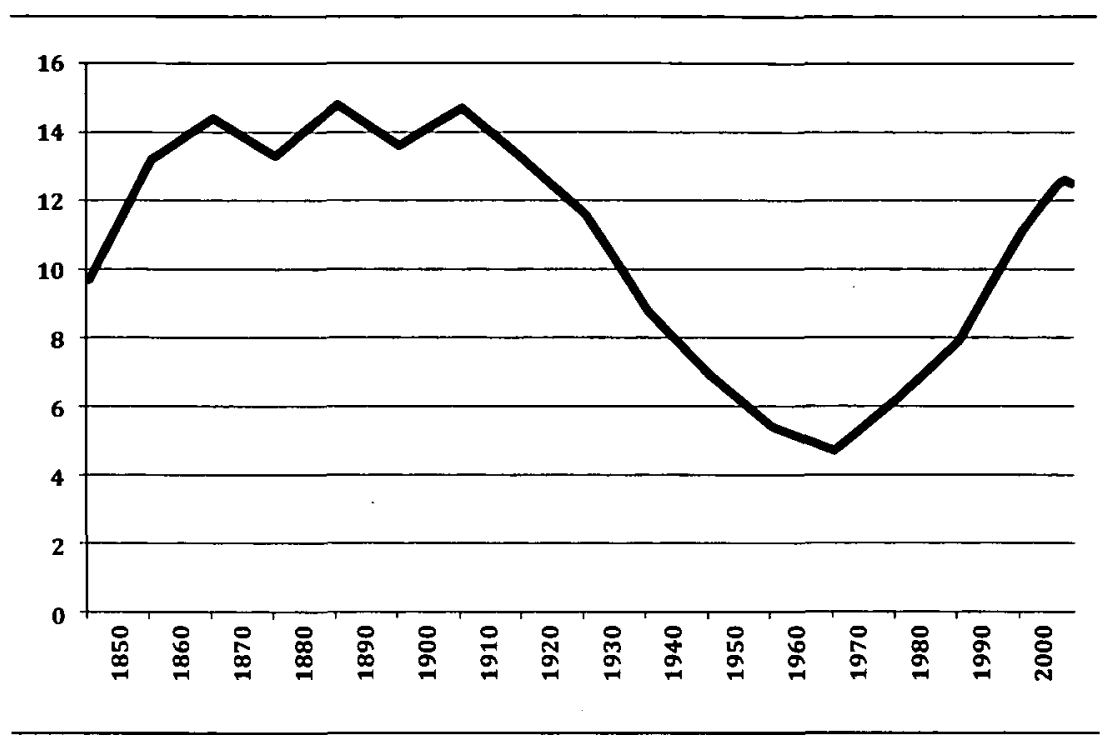

separately-figures that criminologists tend to consider especially reliable (although volatile year to year), because they are close to fully reported and relatively difficult for police departments to massage. ${ }^{114}$

Although the rise of crimmigration cannot be attributed to a growing problem of crime committed by noncitizens, it plainly does have something to do with escalating concerns about immigration-and, more specifically, fear of "criminal aliens." Those concerns rose sharply after the terrorist attacks of September II, 200I, but apprehensions about immigration were on the increase even before those attacks. Part of the explanation may be that immigration itself was on the increase. As Table 15 illustrates, the percentage of the United States population born outside the country, which had fallen steadily for most of the twentieth century, began to rise again in the I970s and has now returned to a level last seen in the I920s. ${ }^{115}$

Table 15 may help to explain why immigration enforcement was becoming increasingly punitive even before September II, 200I. Concerns

114. See, e.g., Zimring, supra note I08, at 4.

IIs. The data in Table 15 are taken from Migration Policy Institute, Foreign-Born Population and Foreign Born as Percentage of the Total US Population, 1850 to 2008, dataset available at www.migrationinformation.org/datahub/charts/MPIDataHub-Number-Pct-FB1850-2008.xls. See also Brookings Institution, State of Metropolitan America: On the Front Lines of Demographic Transformation 65-67 (2010). 
about immigrants may have been fueled in part by rates of immigration. ${ }^{116}$ And those concerns, whatever their causes, plainly have helped to drive tougher enforcement of immigration laws and more draconian treatment of immigrants who are convicted of crimes. Part of the explanation for crimmigration may be nativism.

At best, though, it is an incomplete explanation. We have had periods of nativism before, and they did not involve a blurring of the boundary between immigration enforcement and criminal justice. If crimmigration is a form of backlash, why has the backlash taken this particular form-as opposed, say, to simply tightening immigration quotas, or ratcheting up immigration enforcement in its traditional forms? We need some other explanation for crimmigration and some other lens for understanding it.

\section{B. Criminalization and Cultural Obsession}

One possibility is to understand crimmigration as only one aspect of the broader phenomenon of overcriminalization - the widely discussed, and generally deplored, tendency of criminal law to move into and to colonize areas traditionally addressed, and better addressed, through other modes of governance. ${ }^{117}$ Crimmigration, on this view, simply replicates in the context of immigration what we have already witnessed in fields ranging from corporate malfeasance to domestic violence: the relentless expansion of criminal law. ${ }^{118}$

116. The connection between rising immigration and anti-immigrant policies is far from simple, partly because immigrants themselves gain political power when their numbers increase, and partly because American sentiments about immigration, both pro and con, have deep cultural roots. But even John Higham, who did more than any other historian to draw attention to these complexities, later stressed the importance of "the numerical proportion between newcomers and the resident population" as a driver of ethnic conflict, nativism, and restrictionary immigration policies. John Higham, Strangers in the Land: Patterns of American Nativism, 1860-1925, at 341-43 (paperback ed. 2008). For a thoughtful argument that crimmigration should be understood first and foremost as a cultural response to anxieties and ambivalence about immigration, see McLeod, supra note 8.

117. See, e.g., Douglas Husak, Overcriminalization: The Limits of the Criminal Law (2008).

118. For an early argument along these lines-before September 11, 200I-see Maria Isabel Medina, The Criminalization of Immigration Law: Employer Sanctions and Marriage Fraud, s Geo. Mason L. Rev. 669, 674-76 (1997). 
There is something to be said for this view. Part of what is significant, and troubling, about the rise of crimmigration is precisely the use of criminal prosecutions and prison sentences to address problems traditionally handled mainly as regulatory violations. But there are limitations to this explanation.

To begin with, it is unclear whether criminal law really does expand relentlessly and ubiquitously. It is true that lots of things are crimes that did not use to be treated as crimes, but there are also lots of things that used be crimes—adultery, sodomy, loitering, drinking alcohol — that aren't treated as crimes anymore. ${ }^{119}$ So if immigration law is being criminalized, we would still need to ask why this kind of overcriminalization, and why now?

Second, and more important, it isn't clear that the blurred boundary between criminal law and immigration really is best understood as criminal law expanding into the realm of immigration law, as opposed to immigration law expanding into the realm of criminal law-or something else entirely. The boundary between the two fields definitely has grown less distinct, but it isn't clear that this can usefully be understood as one field colonizing the other. And if there is colonization going on, it isn't clear which field is colonizing which. ${ }^{120}$

A related but more nuanced way to think about the blurred boundary between criminal law and immigration law is to see it as a manifestation not of overcriminalization, exactly, but rather of an escalating cultural obsession with crime and security. My colleague Jonathan Simon, for example, has argued at length that criminal victimization has gone from one social problem among many to our paradigmatic social problem-the most important, and most legitimate, target of government intervention, and the lens through which other social problems are understood and their

119. See Darryl K. Brown, Democracy and Decriminalization, 86 Tex. L. Rev. 223 (2007). Even in the area of immigration, Ingrid Eagly argues that criminal prohibitions have been "fairly static over time," expanding far less than they could; she stresses that "our hybrid immigration system" remains "far broader on the civil side than on the criminal side." Eagly, supra note 8.

120. Cf., e.g., Peter R. Moyers, Butchering Statutes: The Postville Raid and the Misinterpretation of Federal Criminal Law, 32 Seattle U.L. Rev. 651, 688 (2009) (discussing "the inverse of crimmigration, namely, the 'immigrationization' of criminal law . . the use of the criminal justice system to effect goals of immigration law"). 
suitability for government intervention assessed. We live in an era, he says, of "governing through crime." 121

It is hard not to see some of that in crimmigration-hard not to see the "criminal alien" replacing the "freeloading foreigner" as the central, overriding concern of immigration authorities, and the concern invoked most heavily in nativist rhetoric. ${ }^{122}$ In defending Arizona's recent efforts to crack down on illegal immigration, for example, the state's governor did not talk about immigrants using public benefits, the leitmotif of antiimmigration rhetoric a decade or so ago; ${ }^{123}$ she talked about crime. ${ }^{124}$. Part of what has blurred the line between immigration enforcement and crime control may in fact be a kind of cultural obsession with violence and victimization, a tendency to see everything through the lens of crime control.

But that is not the whole story-not even in combination with the rise in anti-immigrant sentiments. It does not explain the particular manner in which the "criminal alien" has been targeted: the way that rapidly proliferating deportations for criminal activity have been matched by skyrocketing immigration prosecutions; the way that local police have become enlisted in immigration work, drawing them away from time they could be spending on violent offenses; the growth of a parallel system of jails and lockups for noncitizens suspected of immigration violations. Nor does it help us understand the double-barreled nature of the crimmigration system, the way that criminal process and immigration process continue to function as separate tracks, even as they seem increasingly focused on the same objectives, and even as the choice between the tracks in a given situation seems increasingly arbitrary.

121. Simon, supra note 9. For related arguments, see Garland, supra note 9; Stuart A. Scheingold, The Politics of Street Crime: Criminal Process and Cultural Obsession (1991). For a thoughtful argument that governance increasingly relies on the criminal process because of the institutional and procedural advantages that, for historically contingent reasons, criminal enforcers have come to enjoy, see Daniel Richman, Overcriminalization for Lack of Better Options: A Celebration of Bill Stuntz, in The Political Heart of Criminal Justice: Essays on Themes of William J. Stuntz 64-86 (Michael Klarman, David Skeel, \& Carol Steiker eds., 2012).

122. For accounts of crimmigration drawing explicitly on Simon's work, see Chacón, Managing Migration, supra note 6; Legomsky, supra note 3.

123. See, e.g., David A. Sklansky, Proposition 187 and the Ghost of James Bradley Thayer, 17 Chicano-Latino L. Rev. 24 (1995).

124. See, e.g., Randal Archibold, Arizona Enacts Stringent Law on Immigration, N.Y. Times, April 24, 20I0, at AI. 


\section{Ad hoc Instrumentalism}

\section{Ad hoc Instrumentalism Described}

Something else is going on here. The something else, I want to argue, is ad hoc instrumentalism. By that I mean a particular way of thinking about law and legal institutions, a way of thinking marked both by skepticism of formal legal categories and by skepticism of the idea that official discretion needs to be, and can be, cabined and controlled. Ad hoc instrumentalism is certainly not a complete explanation for the rise of crimmigration, nor even, perhaps, the most important explanation, but it has helped create conditions hospitable for that development. Aside from its explanatory value, moreover, ad hoc instrumentalism provides a useful descriptive account of certain key features of the our newly merged system of criminal justice and immigration enforcement-features that raise important issues of transparency, accountability, and the rule of law. To defend these claims, though, I need to thicken my description of ad hoc instrumentalism.

The skepticism underlying ad hoc instrumentalism reflects the widespread sense that two intellectual projects of mid-twentieth-century judges and legal scholars proved unworkable. One was the effort to provide a principled dividing line between criminal law and civil law; the other was the effort to make criminal justice less discretionary. The first project was exemplified by Herbert Packer's book, The Limits of the Criminal Sanction, ${ }^{125}$ and it was a part of a broader effort to tie criminal law, in a rationalized and systematic way, to principles of moral philosophy - the effort that found its most famous expression in the Model Penal Code. Packer's project has not been abandoned; there are still efforts to set boundaries for the criminal law in a reasoned, principled fashion. ${ }^{126}$ But they have become much less common. Most scholars of criminal law put their energies elsewhere. Some of them explicitly question the possibility or the desirability of drawing the bounds of criminal liability without drawing on politics and emotion. ${ }^{127}$ Even scholars more committed to rationalizing criminal law, and more confident in the feasibility of that effort, tend to be skeptical that doctrinal categories can be or should be based on anything other than a collective judgment about what sorts of conduct seem to call for a

125. Herbert L. Packer, The Limits of the Criminal Sanction (1968).

126. For a recent, thoughtful example, see Husak, supra note in.

127. E.g., Dan M. Kahan, The Cognitively Illiberal State, 6o Stan. L. Rev. 115 (2007). 
given set of sanctions and procedures. ${ }^{128}$ Among the public, too, there seems to be a general sense that the bounds of criminal law should be set pragmatically, not philosophically. Debates about whether to decriminalize marijuana and other drugs, for example, are dominated by questions of whether criminal enforcement "works," and what the practical consequences of decriminalization should be-not by questions about whether drug use is the kind of thing that deserves to be criminalized. Formal doctrinal dividing lines, such as the distinction between criminal and civil law, are more and more seen as arbitrary: accidents of history rather than moral imperatives.

This way of thinking is linked, of course, to a broader tendency to see law as instrumental and artificial; it is linked, that is to say, to the decline of natural law, customary law, and legal formalism. ${ }^{129}$ But even someone who views law as "an instrument of power" and "an empty vessel to be filled as desired" 130 can believe that doctrinal boundaries, once established, deserve respect. Criminal law has distinct, and distinctively severe, penalties at its disposal, and it is linked, if only by historical accident, to a distinctively strong sense of moral opprobrium; perhaps these characteristics, however contingent historically, carry implications for the situations in which criminal law can properly be invoked. ${ }^{131}$ Honoring those implications might even be thought necessary to preserve the ability of criminal law to do its work, because calling too many things "crimes" might be thought to undermine the label's moral force. These are precisely the kinds of concerns that motivated scholars like Packer and the architects of the Moral Penal Code. They have been undermined by a skepticism that goes beyond denying that law comes from the sky, a skepticism that questions, as well, the stability and coherence of received legal categories-and perhaps the very possibility that categories of this kind could ever be stable and coherent.

Thus the "instrumentalism" of ad hoc instrumentalism. The "ad hoc" part comes from disappointment with the results of a separate project of

128. E.g., William J. Stuntz, The Uneasy Relationship Between Criminal Procedure and Criminal Justice, 107 Yale L.J. I (1997).

129. See, e.g., Brian Z. Tamanaha, Law as a Means to an End: The Threat to the Rule of Law (2006).

130. Id. at $\mathbf{I}$.

I3I. See, e.g., Husak, supra note ir7. 
mid-twentieth-century judges and legal scholars, the effort to rein in the discretion that seemed to run throughout the criminal justice system. Much of the Warren Court's "criminal procedure revolution" aimed to bring police officers under the rule of law by limiting their discretion. ${ }^{132}$ Sentencing reform in the 1970 replaced indeterminate sentences with fixed terms, all but putting parole boards out of business, and used guidelines (which in some cases were all but mandatory) to corral the discretion of sentencing judges. ${ }^{133}$ By the 1990s there was growing disillusion with all of this. The effort to reduce police discretion seemed at best quixotic and at worst incompatible with new and promising approaches to policing. ${ }^{134}$ Determinate sentences and sentencing guidelines seemed only to empower prosecutors, worsen disparities, and make the criminal justice ever more draconian. ${ }^{135}$ In general, criminal justice scholars began to believe that discretion was both necessary and inevitable: efforts to eliminate it or to control it merely shifted it elsewhere in the system. ${ }^{136}$ By the end of the twentieth century, there was widespread disenchantment among criminal justice scholars and reformers with the general project of reining in official discretion.

The disenchantment was, and still is, far from complete. Some scholars and reformers remain committed to the project of reining in police discretion. ${ }^{137}$ And there is widespread concern about the power placed in the hands of prosecutors-especially given the manner in which mandatory sentences and sentencing guidelines have reduced the sanctioning discretion of trial

132. See, e.g., David Alan Sklansky, Democracy and the Police 44-48 (2008); Tracey L. Meares, Terry and the Relevance of Politics, 72 St. John's L. Rev. 1343 (1998).

133. E.g., Jonathan Simon, Poor Discipline: Parole and the Social Control of the Underclass, 1890-1990, at 230-39 (1993).

134. See, e.g., Dan M. Kahan \& Tracey L. Meares, Foreword: The Coming Crisis of Criminal Procedure, 86 Geo. L.J. I153 (1998); Debra Livingston, Police Discretion and the Quality of Life in Public Places: Courts, Communities, and the New Policing, 97 Colum. L. Rev. 55I (1997).

135. See, e.g., Mary Price, Everything Old is New Again: Fixing Sentencing By Going Back to First Principles, 36 New Eng. J. Crim. \& Civ. Confinement 75 (2010).

136. See, e.g., Simon, supra note 133, at 7-8; Nancy Gertner, Sentencing Reform: When Everyone Behaves Badly, 57 Me. L. Rev. 569, 57I (2005); but cf. Terance Miethe, Charging and Plea Bargaining Practices Under Determinate Sentencing: An Investigation of the Hydraulic Displacement of Discretion, 78 J. Crim. L. \& Criminology 155 (1987) (providing evidence that discretion did not inevitably relocate).

137. See, e.g., David Cole, Discretion and Discrimination Reconsidered: A Response to the New Criminal Justice Scholarship, 87 Geo. L.J. 1059 (1999). 
judges. ${ }^{138}$ But for the most part, concern about prosecutorial power have not prompted efforts to further reduce discretion: instead, it has prompted calls to shift discretion back to judges, ${ }^{139}$ or less commonly, to help prosecutors exercise their discretion more thoughtfully. ${ }^{140}$ Meanwhile there is renewed interest in the idea that justice should be tempered by mercy. ${ }^{141}$ Because its exercise required a departure from uniform rules and standards, mercy fell from favor in the I960s and 1970s; it seemed like a polite word for favoritism. It was lawless. ${ }^{142}$ The renewed interest in mercy therefore draws strength from, and in turn bolsters, the growing comfort with-or, at least, acceptance of - the broader role of discretion in criminal justice.

Combine that comfort or acceptance-the turn away from what one scholar pejoratively calls "discretion skepticism" 143 — with the widespread sense that formal doctrinal categories are arbitrary accidents of history, and it begins to seem obvious that ground-level officials should be encouraged and enabled to use whatever legal tools give them the most leverage against particular, threatening individuals. Ad hoc instrumentalism, that is to say, begins to make a lot of sense.

Ad hoc instrumentalism is related to, but goes beyond, some more familiar kinds of decentralized enforcement authority in the criminal justice. Most obviously, it is related to prosecutorial discretion: the widespread and widely accepted practice of trusting prosecutors to decide whether particular charges, although legally justified, should nonetheless not be brought, or should be bargained away as part of a plea agreement. Ad hoc

138. See, e.g., Angela J. Davis, Arbitary Justice: The Power of the American Prosecutor (2007); Price, supra note 135 .

139. See, e.g., William J. Stuntz, Unequal Justice, 12r Harv. L. Rev. 1969, 2039 \& n.327 (2008); Price, supra note 135 .

I40. See, e.g., Rachel E. Barkow, Organizational Guidelines for the Prosecutor's Office, 3I Cardozo L. Rev. 2089 (2010); Rachel E. Barkow, Institutional Design and the Policing of Prosecutors: Lessons from Administrative Law, 6r Stan. L. Rev. 869 (2009).

I4I. See, e.g., Rachel E. Barkow, The Ascent of the Administrative State and the Demise of Mercy, 121 Harv. L. Rev. 1332 (2008); Carol Steiker, Tempering or Tampering? Mercy and the Administration of Criminal Justice, in Forgiveness, Mercy and Clemency (Austin Sarat \& Nasser Hussain eds., 2007).

142. See Barkow, supra note I4r; Carol S. Steiker \& Jordan M. Steiker, Let God Sort Them Out? Refining the Individualization Requirement in Capital Sentencing, IO2 Yale L.J. 835 (1992).

143. Meares, supra note 132, at 1344-45; cf. Simon, supra note 133 , at 7-8 (discussing the "[f]light from [d]iscretion"). 
instrumentalism bears a particularly close resemblance to one particular form of prosecutorial discretion, what is sometimes called "pretextual prosecution": pursuing a defendant suspected of one crime by charging a less serious but more easily provable crime. ${ }^{144}$ Like prosecutorial discretion more generally, pretextual prosecution is widely if grudgingly accepted as appropriate. ${ }^{145}$ The broad acceptance of these practices reflects both the decline of "discretion skepticism" and the withering of legal formalism. We give prosecutors such broad power, and we are relatively untroubled by their use of one criminal statute to attack conduct addressed, on the face of it, by a different statute, because trusting front-line officials seems necessary, and because it seems natural to us to view laws simply as tools. If the best way to drive a particular nail happens to be a socket wrench, then so be it: there is no moral imperative to drive nails with hammers rather than wrenches, or to charge gangsters with murder and extortion rather than tax evasion.

These are the same ideas driving ad hoc instrumentalism. But ad hoc instrumentalism goes beyond prosecutorial discretion and even pretextual prosecution; in a sense, it takes the practice of pretextual prosecution to its logical conclusion. Rather than simply empower prosecutors to use the criminal code as a set of tools, ad hoc instrumentalism empowers a wider range of front-line officials, including but not limited to prosecutors, to view all substantive laws and all enforcement regimes, criminal and civil, as tools to be employed strategically, as the circumstances demand.

\section{Ad hoc Instrumentalism in Action}

Crimmigration - the merged system of criminal justice and immigration enforcement-is a particularly good example of ad hoc instrumentalism at work. ${ }^{146}$ Two formally separate but increasingly interconnected bodies of

\footnotetext{
144. See, e.g., Litman, supra note 82; Daniel C. Richman \& William J. Stuntz, Al Capone's Revenge: An Essay on the Political Economy of Pretextual Prosecution, ros Colum. L. Rev. 583 (2005).

145. See Richman \& Stuntz, supra note 144, at 584-95; but cf. Erin Murphy, Manufacturing Crime: Process, Pretext, and Criminal Justice, 97 Geo. L.J. 1435 (2009) (raising concerns about certain categories of pretextual prosecutions).

146. Ingrid Eagly has made a somewhat similar point, stressing the new, "collaborative relationship" between the immigration enforcement system and the criminal justice system. See Eagly, supra note 8.
} 
law and procedure are each trained on the same perceived threat: the criminal alien. Law enforcement agents, prosecutors, and immigration officials are encouraged to see criminal law and immigration law simply as different kinds of tools, and to use whichever tool works best against a particular offender or suspect. ${ }^{147}$ Often the tools will work best in combination, so individuals are shunted back and forth between the criminal justice system and the immigration enforcement system, or targeted by both simultaneously: illegal border crossers are placed in immigration detention, then serve time in jail or prison, and then are deported; or individuals suspected of being in the country illegally are arrested for traffic infractions or "quality of life" misdemeanors, and then transferred to immigration authorities if the suspicion proves well founded. ${ }^{148}$ Immigration tools can be used to bolster criminal prosecution: a "hold" for immigration detention can be used, for example, to deny bail to a noncitizen charged with a crime. ${ }^{149}$ And criminal prosecutions can be used to achieve immigration objectives: by convicting noncitizens of crimes that trigger mandatory deportation, or by insisting (as prosecutors increasingly do) that plea agreements include a waiver of claims that might otherwise block deportation, or simply by substituting (as prosecutions under Operation Streamline often do) criminal for civil removal proceedings, taking advantage of the threat of lengthy criminal sentences. ${ }^{150}$

If crimmigration were the only site of ad hoc instrumentalism, it would make sense to see ad hoc instrumentalism purely as a consequence rather than a cause, an attribute of our merged system of criminal law and immigration enforcement, but no part of the explanation for that merger. But the increasing popularity of ad hoc instrumentalism can be seen outside the context of crime and immigration, as well; it seems, in fact, to be a

147. ICE describes Operation Community Shield, for example, as an effort "to use all of our tools to disrupt and dismantle" criminal gangs. See Semple, supra nore 64, at A23 (quoting James T. Hayes Jr., Special Agent in Charge, Investigations Division, Immigration and Customs Enforcement).

148. See, e.g., Trevor Gardner II \& Aarti Kohli, Chief Justice Earl Warrant Institute on Race, Ethnicity \& Diversity, The C.A.P. Effect: Racial Profiling in the ICE Criminal Alien Program (2009); Eagly, supra note 8.

149. See Eagly, supra note 8. Eagly notes that criminal prosecutions can also take advantage of evidence gathered by immigration investigators, free from some of the constraints placed on criminal investigators by the Fourth and Fifth Amendments. See id.

Iso. See id. 
widespread if not pervasive feature of our current legal culture. In policing, for example, there is the growing enthusiasm among both officers and scholars for "pulling levers"- the idea that the police should identify the worst offenders, warn them to desist, and then, if the warning goes unheeded, work hand-in-hand with other government agencies to pull whatever legal levers are most effective in removing the offenders from the community. Sometimes it is state prosecution, sometimes it is federal prosecution, sometimes it is eviction from public housing, sometimes it is parole or probation revocation, and sometimes it is deportation. ${ }^{151}$ This approach has been widely credited, for example, with helping to produce the "Boston Miracle" - the sharp drop in youth violence in Boston during the I990s." ${ }^{152}$

Ad hoc instrumentalism also characterizes-in a taken-for-granted kind of way - the way we tend to think about and talk about national security. A decade ago national security work was kept largely separate from criminal justice work. The agencies responsible for national security-the Central Intelligence Agency, the National Security Administration, and various intelligence services within the Department of Defense-generally did not share their files with criminal justice agencies. Special findings were needed when officials thought it appropriate to breach the wall dividing criminal investigations from national security investigations. But that was before the terrorist attacks of September II, 200I. One of the lessons drawn from those attacks was precisely the need to lower the wall dividing national security work from criminal justice work. Law enforcement agencies now routinely share information with national security agencies. A network of "fusion" centers has been set up across the country precisely to facilitate this kind of sharing, as well as the coordination of federal, state, and local law enforcement efforts. ${ }^{153}$

I5I. See, e.g., David M. Kennedy, Old Wine in New Bottles: Policing and the Lessons of Pulling Levers, in Police Innovation: Contrasting Perspectives 155 (2006).

152. See, e.g., id. at 157-58; Kennedy, Braga, \& Piehl, supra note 65. The drop proved temporary, and in retrospect seems to have relied, in part, on collaboration and hard-won trust berween the Boston Police Department and a network of community leaders, especially clergy associated with large-scale street ministries. See Anthony A. Braga, David Hureau, \& Christopher Winship, Losing Faith? Police, Black Churches, and the Resurgence of Youth Violence in Boston, 6 Ohio St. L.J. 14I (2008).

153. Danielle Keats Cirron \& Frank A. Pasquale III, Nerwork Accountability for the Domestic Intelligence Apparatus, 62 Hastings L.J. I44I (2OII). 
The formal rationale for fusion centers — and, more broadly, for lowering the wall between criminal justice and national security investigators, and increasing the coordination of federal, state, and local law enforcement-is to leverage manpower and resources. The idea is to allow national security agencies to take advantage of information uncovered as a byproduct of criminal justice investigations, and vice versa. In practice, though, fusion centers and related efforts at interagency cooperation have also facilitated a leveraging of legal authority, allowing national security officials to take advantage of the powers granted to law enforcement officials, and vice versa. ${ }^{154}$ This kind of legal leverage, of course, is exactly what the old wall between law enforcement work and national security work was designed to prevent. The wall could have been lowered to allow more leveraging of manpower and resources without authorizing wholesale leveraging of legal authority; one could imagine a series of rules designed to sort information uncovered incidentally, in the course of an investigation aimed at what the agency was supposed to be investigating, from information obtained through the purposeful use of, say, criminal justice powers to advance national security ends. By and large, rules of that kind have not been developed or even attempred in the wake of September II, 200I. Part of the reason, certainly, is that many have thought it best not to run the risk of erroneously failing to share information obtained incidentally. But another part of the reason is ad hoc instrumentalism: the entire effort to confine agencies to their mission has seemed artificial and overly formalistic.

For cases falling near the boundary of criminal law and national securitynotably terrorism cases-ad hoc instrumentalism has influenced not only methods of investigation but also modes of prosecution. Since $9 /$ II there has been considerable disagreement about the proper way to adjudicate terrorism cases: are these cases appropriately handled in Article III courts, in military courts, in military tribunals, or in some other forum? The Obama administration has answered this question with ad hoc instrumentalism, announcing its intention to decide on case-by-case basis what forum seems best. ${ }^{155}$

154. See, e.g., id.

155. See, e.g., President Barack Obama, Speech at the National Archives Museum: Protecting Our Security and Our Values (May 21, 2009), www.whitehouse.gov/the_press_office/ Remarks-by-the-President-On-National-Security-5-21-09/; Glenn M. Sulmasy and Andrea K. Logman, The Appropriate Venue for Trying Terrorist Case: A Hybrid Court for a Hybrid War, ${ }_{42}$ Case W. Res. J. Int'l L. 29 (2009); Charlie Savage, U.S. to Try Avowed 9/11 Mastermind Before Civilian Court in New York, N.Y. Times, Nov. 14, 2009, at Ar. 
Table 16. Parole population, 1980-2008

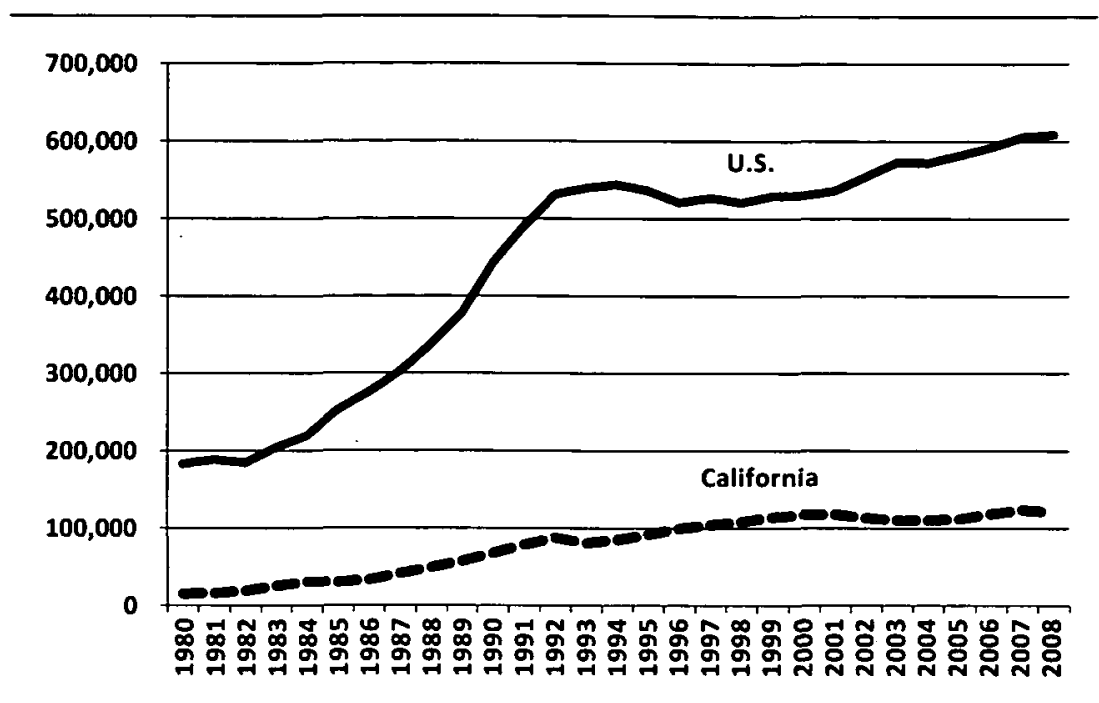

Outside of the context of crime and immigration, though, the area marked most strikingly by ad hoc instrumentalism may be parole. Over the last few decades-beginning roughly in the 1970s-parole has morphed from a system for reintegrating ex-felons into the community, into a system for sending them back to prison more quickly, and with fewer procedural hurdles, than could be accomplished with a new criminal conviction. ${ }^{156}$ As rates of incarceration grew in 1970s, 1980s, and 1990s, so did the number of parolees released back into society. ${ }^{157}$

As Table 16 illustrates, the nation's parole population rose by more than 250 percent between 1980 and $2008 .^{158}$ The pattern has been particularly

156. See Alfred Blumstein \& Allen J. Beck, Reentry as a Transient State Between Liberty and Recommitment, in Prisoner Reentry and Crime in America so (Jeremy Travis \& Christy Visher eds., 2005); Simon, supra note 133, at 203, 208; Jeremy Travis \& Kirsten Christiansen, Failed Reentry: The Challenges of Back-End Sentencing, 8 Geo. J. Poverty L. \& Pol'y 249 (2006).

I57. "At year-end 2007, nearly 825,000 adult men and women were under parole supervision in the United States, nearly four times the number on parole in 1980." Elizabeth C. McBride, Note, Policing Parole: The Constitutional Limits of Back-End Sentencing, 20 Stan. L. \& Pol'y Rev. 597, 601 (2009).

158. The data in Tables 16, 17, and 18 are taken from parole statistics maintained the United States Bureau of Justice Statistics. The figures were collated from Matthew Cooper, 
stark in California, where a period of parole is mandatory for virtually every released prisoner. ${ }^{159}$ California's parole population has increased by an order of magnitude over the last three decades. ${ }^{160}$ At the same time, rates of parole revocation have also risen dramatically-and again, the pattern is especially pronounced in California, although the rest of the nation is slowly catching up. ${ }^{161}$ The revocation rate for California parolees - the fraction of parolees returned to prison each year-has increased from roughly is percent in the mid-1970s to upward of 60 percent today, and the vast majority of these returns take the form of parole revocations rather than new convictions. ${ }^{162}$ Table 17 shows the trajectories.

The result has been that a large and growing fraction of prison admissions are the result of parole revocations rather than criminal convictions. ${ }^{163}$ In California, roughly two-thirds of the people sent to prison each month are sent there by parole revocations, not by new criminal convictions. ${ }^{164}$ Nationwide, the figure is just south of 40 percent. Table 18 shows the trends.

Nominally, parole still serves the purpose of "promoting reintegration and positive citizenship,"165 while also "reduc[ing] the costs of criminal punishment" and maintaining "a degree of supervision over the parolee." ${ }^{166}$ In

William J. Sabol, \& Heather C. West, Prisoners in 2008, at fig. 4 \& appdx. 12 (2009); Bureau of Justice Statistics, United States Department of Justice, Spreadsheets, bjs.ojp. usdoj.gov/content/dtdata.cfm\#corrections ("Prisoners sentenced to more than one year who were admitted to state or federal jurisdiction, 1977-98"; "New court commitments sentenced to more than one year who were admitted to state or federal jurisdiction, 1977-98"; and "Conditional release violators sentenced to more than one year, returned to state or federal jurisdiction, 1977-98"); Bureau of Justice Statistics, United States Department of Justice, Annual Probation Survey and Annual Parole Survey, bjs.ojp.usdoj.gov/ index.cfm?ty=dcdetail\&iid=27I ("Adults on parole in the United States, 1975-2008"); and data on state and federal prison admissions from 1999 through 2007 , provided in response to an email request.

I59. See McBride, supra note 157 , at 601 \& n.22.

I6o. See id. at 6or.

16r. See Simon, supra note 133, at 209 tbl. 7.1.

162. See McBride, supra note 157 , at $603-4 \&$ fig. I. The absolute number of parolees returned to prison each year in California has increased by a factor of forty since the mid1970s. See id. at 603, 605 fig. 2.

163. See Simon, supra note 133 , at 210 tbl. 7.2.

164. See McBride, supra note 162, at 601-5; Simon, supra note 133, at 210 tbl. 7.2 .

165. Samson v. California, 547 U.S. 843, 853 (2006).

166. Pennsylvania Board of Probation \& Parole v. Scott, 524 U.S. 357, 367 (1998). 
Table 17. Parole violation rate, 1980-2008

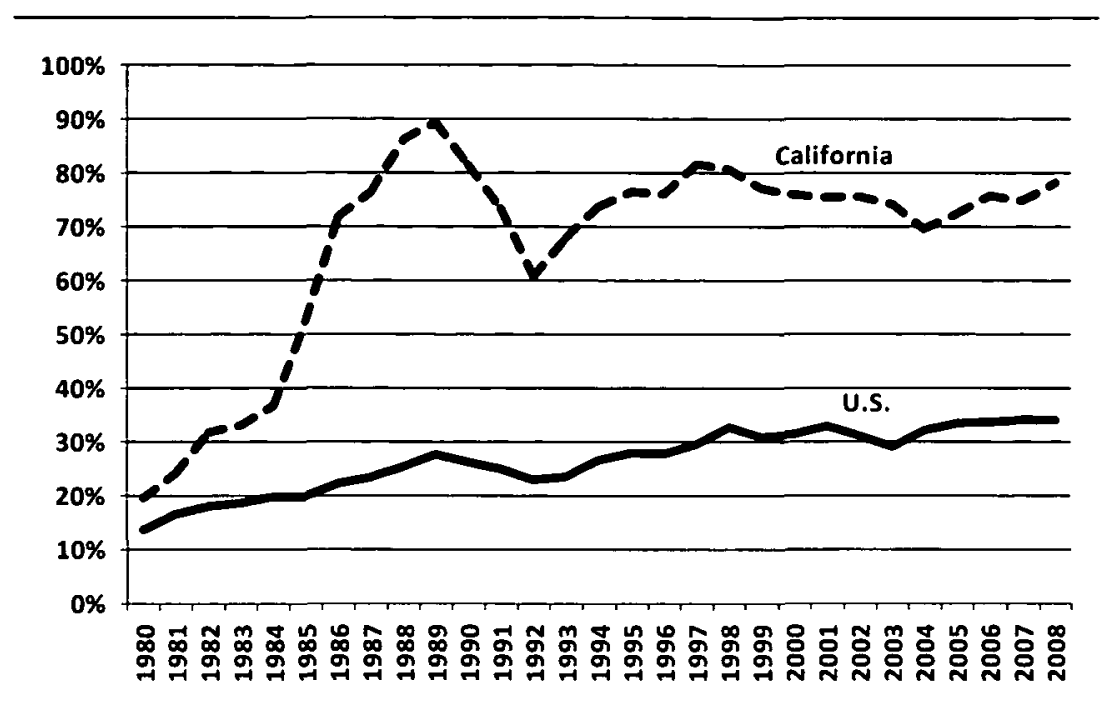

practice, though, parole serves largely as a period during which ex-offenders may be stopped, searched, and re-imprisoned without meeting the normal requirements of the Fourth Amendment or the procedural protections attendant to a criminal trial. Efforts to limit parole searches and parole revocation proceedings to actions in furtherance of "probationary purposes," as opposed to normal criminal justice purposes, have been unsuccessful, as have arguments that stops and searches of parolees carried out by police officers rather than parole staff should be treated as regular stops and searches rather than "parole" stops and searches. ${ }^{167}$ For the large and growing population of parolees, parole supervision functions as a parallel enforcement track, with lower procedural hurdles but a set of available sanctions that often (although far from always) will be less severe than the sanctions that would be triggered by a new criminal conviction. That is to say that parole serves the same function with respect to parolees that immigration law serves for noncitizens: a separate enforcement track that low-level officials can elect to pursue, in lieu of normal criminal enforcement, when it appears convenient.

In parole-as in immigration, policing, and national security-it has become increasingly natural to think of the boundaries separating various kinds of investigatory and enforcement actions by the government, and the

167. See, e.g., United States v. Knights, 543 U.S. 112 (2001). 
Table 18. Percent of prison admissions from parole violations, 1980-2008

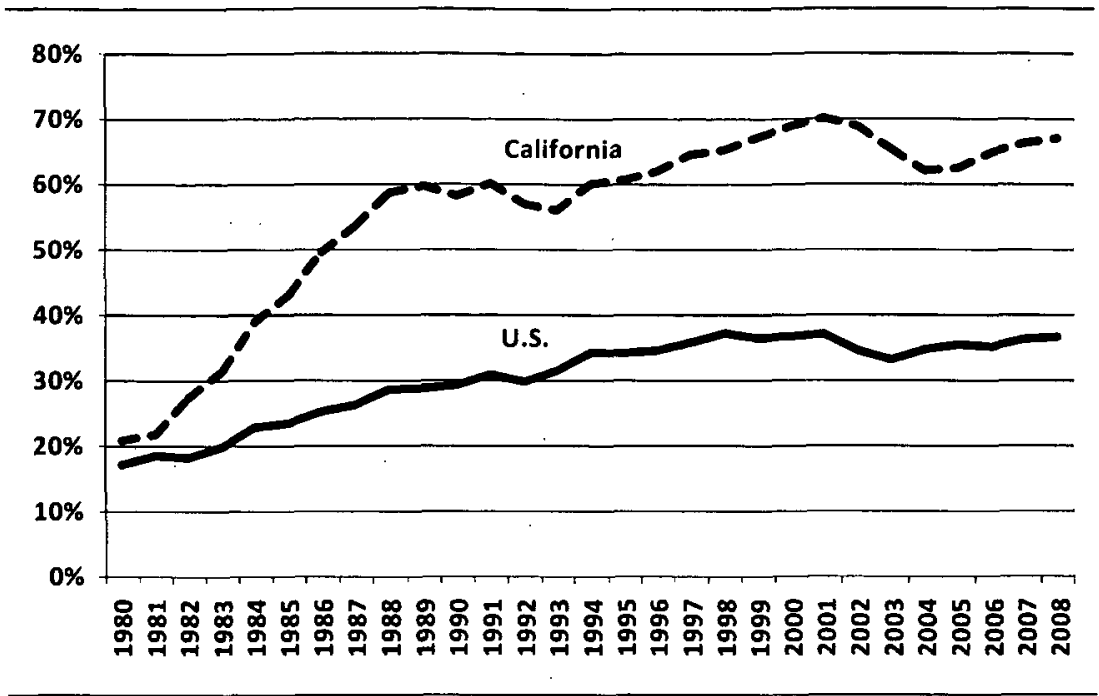

legal boundaries they reflect, as historical accidents, and to think that lowlevel discretion should be empowered rather than constrained. We are in a period in some ways parallel to the moment in English legal history when pleading by fiction transmuted forms of action from tailored sets of requirements for particular kinds of lawsuits into a menu of procedural options from which litigants were allowed and encouraged to choose. That historical development turned over power to litigants; ours is handing power to lowlevel government officials. In each case, the development reflects both a comfort with devolving decision-making authority (in one case to private parties, in the other to executive officers) and a sense that inherited legal categories are arbitrary-or at least that the lines between those categories are sufficiently artificial that nothing substantive need turn on them. ${ }^{168}$

168. The "pulling levers" mindset, and the more particular idea that immigration enforcement can and should serve as a tool of crime control, is becoming commonplace not only in legal culture but in popular culture as well. For example, in the inaugural episode of the newly revived television series, Hawaii $5-0$, the police got a crime boss to cooperate by threatening deportation of his wife and his son. Not incidentally, the crime boss's main line of business was also immigration-related: he was a human smuggler. And the cooperation the police wanted from him was help locating not a home-grown psychopath (the typical malefactor in the show's earlier incarnation) but a foreign terrorist the smuggler had helped slip into the country. Hawaii 5-O: Pilot (CBS television broadcast, Sept. 20, 2010). 


\section{LEGALITY AND ACCOUNTABILITY}

Ad hoc instrumentalism has significant strengths. It is pragmatic. It steers clear of empty formalism. It avoids, too, the effort to rein in the discretion of low-level officials-an effort that can often seems quixotic at best. Instead, it takes advantage of frontline discretion to facilitate tailored enforcement decisions, making maximally effective use of available legal resources in each parricular case. There are reasons this way of thinking about the law has gained popularity.

But there are also grounds for concern about the spread of ad hoc instrumentalism-especially in the context of crime and immigration, but elsewhere as well. I want to flag two concerns. They overlap but sound in different registers. The first concern is about the rule of law, and the second is about accountability. The first concern is the more obvious of the two: intuitively, the rule of law seems a nice way of identifying precisely what ad hoc instrumentalism seems to leave behind. But giving content to that intuition proves difficult. It is hard to spell out what we mean by the rule of law and how, precisely, ad hoc instrumentalism or crimmigration, more specifically, threatens it. The concern about accountability is easier to spell out. The disappearing boundary between criminal law and immigration enforcement threatens accountability in ways that are relatively straightforward to identify, some having to do with ad hoc instrumentalism and some having to do with other defining characteristics of the emerging regime of crimmigration.

\section{A. Rule of Law}

The "rule of law" is a notoriously vague concept, but it retains its rhetorical force largely because it serves to summon a cluster of ideas with deep resonance. $^{169}$ One of those ideas is that government power should be exercised according to rules rather than official whim, the idea that we should have a government of laws, not men. For some people, this is the very essence of the rule of law: "Stripped of all its technicalities," the rule of law "means that government in all its actions is bound by rules fixed and announced beforehand-rules that make it possible to foresee with

169. See Richard H. Fallon Jr., "The Rule of Law" as a Concept in Constitutional Discourse, 97 Colum. L. Rev. I, Io-24 (1997). 
fair certainty how the authority will use its coercive powers in given circumstances, and to plan one's individual affairs on the basis of this knowledge." 170

Ad hoc instrumentalism seems at war with that ideal. It seems troublingly close to what Justice Robert Jackson, when he was United States Attorney General, called "the greatest danger of abuse in prosecuting power": namely, "picking the man and then searching the law books, or putting investigators to work, to pin some offense on him." ${ }^{171}$ Jackson was worried, in particular, about prosecution becoming "personal"; he was worried about situations where "the real crime becomes that of being unpopular with the dominant or governing group, being attached to the wrong political views, or being personally obnoxious to or in the way of the prosecutor himself." 172 That danger may be less acute when we are talking about choosing the most advantageous avenue of enforcement-criminal versus civil, for example, or prosecution versus parole revocation-rather than what Jackson was discussing, the decision whether to institute any enforcement action at all. But there still is something disquieting about asking low-level officials to identify troublemakers - gang affiliates, say, or people who for some other reason seem especially dangerous - and then to select among options like immigration enforcement, parole revocation, or criminal prosecution, depending on which seems most advantageous, rather than on the nature of the offense, whether proven or just suspected. It can seem to license, in a limited way, a kind of petty tyranny. ${ }^{173}$

To most observers, though, rhetoric about tyranny and the rule of law seems exaggerated and out of place today when talking about low-level choices between alternative enforcement regimes. In part that is because we have grown less suspicious of low-level discretion and less sanguine

170. F.A. Hayek, The Road to Serfdom 54 (1994); see also, e.g., Joseph Raz, The Rule of Law and Its Virtue, in The Authority of the Law 210, 210, 219 (1979); Tamanaha, supra note I29, at 227-28; cf. Antonin Scalia, The Rule of Law as a Law of Rules, 56 U. Chi. L. Rev. II75 (1989).

171. Robert H. Jackson, The Federal Prosecutor, 3I J. Am. Jud. Soc'y 3, 5 (1940).

172. Id.

173. Cf. Johnson v. United States, 333 U.S. 10, 17 (1948) (Jackson, J.) (requiring police officers to have probable cause and a judicial warrant before searching a hotel room, because "any other rule . . . would obliterate one of the most fundamental distinctions between our form of government, where officers are under the law, and the police-state where they are the law"). 
about the possibilities of eliminating it, or even reducing it significantly. Low-level discretion has come to seem ubiquitous and unavoidable. Police officers decide countless times every day whether or not to arrest someone for whom they have probable cause; they do not and, as a practical matter, could not arrest everyone they have reason to believe has violated one or another criminal prohibitions. Prosecutors do not and, as a practically matter, could not seek indictments for everyone for whom they have sufficient evidence of criminality. Immigration officers do not, and as a practical matter could not, seek to deport everyone they have reason to believe is illegally in the country. And so on.

The ubiquity and inevitability of low-level enforcement discretion are the principal reasons that concerns about pretextual prosecution, and pretextual enforcement more broadly, tend to be dismissed or downplayed both by judges and by scholars. If prosecutors cannot charge all tax evaders, why shouldn't they focus their efforts on the ones they suspect have also committed more serious crimes? ${ }^{174}$ If the police cannot stop all traffic violators, why shouldn't they focus their energies on the ones they suspect may be transporting contraband? ${ }^{175}$ When "crimes must be enforced sparingly, yet still enforced," focusing on "defendants suspected of other crimes conserves investigative resources and reduces the risk of serious injustice." 176

For similar reasons, it is difficult to develop a rigorous critique of crimmigration, or ad hoc instrumentalism more broadly, using the language of the rule of law. That language purs a name to the vague unease many people may feel about low-level officials deciding which noncitizens, although not provably criminal, nonetheless seem sufficiently threatening to be targeted for administrative detention or deportation, and which illegal entrants into the country should be criminally prosecuted, which should simply be deported, and which should be left alone. But the rule of law is itself too vague an ideal to help clarify what is particularly worrisome about crimmigration and ad hoc instrumentalism, or how those worries could be usefully addressed. As rhetoric, the rule of law can serve as a useful reminder that ad hoc, instrumental decisions at the intersection of criminal justice and immigration enforcement should not be driven exclusively by

174. See Litman, supra note 82.

175. Cf. Whren v. United States, 517 U.S. 806 (1996).

176. Richman \& Stuntz, supra note 144 , at 595 . 
concerns about crime, physical security, and border integrity-a reminder that fairness, dignity, and humane treatment are important, too. But if crimmigration and ad hoc instrumentalism themselves raise new and serious concerns for the rule of law, it must be because they license low-level discretion in some way more extreme or more worrisome than the enforcement discretion that police officers, prosecutors, immigration officials, and other front-line government agents have always exercised. Rule-of-law rhetoric is a blunt tool for identifying those points of departure. Fortunately, the related ideal of accountability proves more useful.

\section{B. Accountability}

One component of the rule of law - of the cluster of ideas summoned by rule-of-law rhetoric - is the desirability of formal, legal constraints on official action. That is the idea behind the notion of a government of laws, not of men. And that idea, in turn, can be understood in part as an appeal for accountability_-for keeping government officials in check. The ideal of accountability thus overlaps with the ideal of the rule of law, but it overlaps only partly. In fact, one of the signal contributions of the last two decades of criminal procedure scholarship has been showing that there are other tools for this, as well, and that political control of the criminal justice may be as important as, or more important than formal, legal constraints in keeping the system balanced, measured, and just. ${ }^{177}$

One reason for that is the radical decentralization of law enforcement in the United States. Policing is overwhelmingly a local responsibility, and criminal punishment is overwhelmingly a state responsibility. The federal government, for the most part, plays only a supporting role-even after September II, 200I. Constitutional dictates handed down by nine justices in Washington, D.C.,

177. A disproportionate share of that contribution came from a single scholar. See Stuntz, supra note 139, at 1969; William J. Stuntz, The Political Constitution of Criminal Justice, II9 Harv. L. Rev. 780 (2006); William J. Stuntz, The Pathological Politics of Criminal Law, roo Mich. L. Rev. sos (2001); William J. Stuntz, Local Policing After the Terror, III Yale L.J. 2137 (2002); William J. Stuntz, Race, Class, and Drugs, 98 Colum. L. Rev. 1795 (1998). For other important work on the political economy of criminal justice, see Daniel Richman, Political Control of Federal Prosecutions: Looking Back and Looking Forward, 58 Duke L.J. 2087 (2009); Daniel C. Richman, The Past, Present, and Future of Violent Crime Federalism, 34 Crime \& Just. 377 (2006); Daniel C. Richman, "Project Exile" and the Allocation of Federal Law Enforcement Authority, 43 Ariz. L. Rev. 369 (200I). 
are at best a cumbersome and indirect way to control fifty-plus separate systems of criminal adjudication across the country and thousands of local law enforcement agencies. Local political control is a more powerful lever. It remains an open question how reliably that lever improves rather than impairs the faimess of American criminal justice, but-at a minimum-political controls almost certainly do more than legal constraints to make criminal justice accountable. Even for federal law enforcement agencies, congressional oversight-sometimes in the form of statutory directives, sometimes simply in the form of hearings - can be as important as, or more important than, judicially enforced constraints.

Because immigration enforcement has been more or less a federal monopoly, the opportunities for keeping the system accountable at the local level have been more limited. At the federal level, too, the immigration system has often seemed resistant to political redirection, for good or for ill, and immigration officials have long operated less openly than criminal justice officials. The Immigration and Naturalization Service was notorious for its culture of secrecy, and ICE has inherited some of that culture.

Nonetheless, the immigration enforcement system, like the criminal justice system, has always faced political as well as legal constraints. And as immigrants have become a larger and larger share of the United States population, their political voice has grown louder, and public interest organizations dedicated to their welfare have gained support and influence. Immigrants are hardly a monolithic group, of course, and documented immigrants, in particular, are not always sympathetic to the concerns of the undocumented. But the divide between the two groups of immigrants is highly porous. Many documented immigrants were earlier undocumented or have friends or family members who were or remain undocumented, and a large share of undocumented immigrants live in households with United States citizens or with noncitizens who are lawful residents. ${ }^{178}$

Partly because of the growing number of immigrants in the United States, ICE faces a network of public interest watchdogs far stronger and more attentive today than at any time in the past half-century. ${ }^{179}$ Some

178. See, e.g., Jeffrey S. Passel \& D'Vera Cohen, Pew Hispanic Center, A Portrait of Unauthorized Immigrants in the United States (2009).

179. At the national level alone, see, for example, the websites maintained by the ACLU Immigrants' Rights Project (www.aclu.org/immigrants-rights); the American Immigration Council (www.americanimmigrationcouncil.org); Amnesty International USA's Refugee Program (www.amnestyusa.org/refugees-and-asylum/page.do?id=1011010); the Detention 
of those organizations lobby for more aggressive immigration enforcement, but more push for better treatment of immigrants. And they have an impact. Some of their successes, moreover, have increased their leverage by making the activities of ICE more transparent and easier to monitor. Recently, for example, ICE introduced an online system for tracking immigration detainees, making it easier for advocacy groups to keep track of detainees and to stay in touch with them. ${ }^{180}$

The blurred boundary between criminal justice and immigration enforcement, and the ad hoc instrumentalism moving more and more cases across that boundary, has complicated efforts to hold criminal and immigration officials accountable through political oversight and public pressure. We have reasonably clear lines of responsibility for criminal justice decisions: police are responsible for who gets detained, who gets arrested, and how those steps are carried out; prosecutors are responsible for who gets charged, what they get charged with, and how the cases are litigated; judges and juries are responsible for how criminal cases are decided; prison officials are responsible for conditions of confinement; and parole officers are responsible for supervising offenders after release from prison. The lines of responsibility for the treatment of people charged with immigration violations have never been as clear, but at least it used to be straightforward to identify the responsible agency: the Immigration and Naturalization Service.

Crimmigration has changed this. In a growing number of cases, it is difficult if not impossible to determine who is responsible for the treatment of noncitizens caught up in the merged system of criminal justice and immigration enforcement-not only which officials, but which branch of government. I mean this in two different ways. First, it is frequently difficult to determine where particular decisions were made: for example, which officials, or even which agency, chose to transport an undocumented alien out of the country,

Watch Network (www.detentionwatchnetwork.org); Familes for Freedom (www.familiesforfreedom.org); the National Counsel of La Raza (www.nclr.org); the Immigrant Defense Project (www.immigrantdefenseproject.org); the Immigrant Legal Resource Center (www. ilrc.org); the National Immigration Forum (www.immigrationforum.org); the National Immigration Justice Center (www.immigrantjustice.org); the National Lawyers Guild's National Immigration Project (www.nationalimmigrationproject.org); the National Network for Immigrant and Refugee Rights (www.nnirr.org); the National Immigrant Solidarity Network (www.immigrantsolidarity.org); and the Rights Working Group (www. rightsworkinggroup.org).

180. See supra note I03. 
and where to leave her. Second, even when the decision makers can be pinpointed, there are typically more than one of them, and it can be difficult to determine who should be credited or blamed: which officials, or even which agency, should be expected to assess the appropriateness of particular actions. It can also be difficult to determine which agency is responsible, in both of these senses, for programmatic decisions-like, for example, whether to allow localities to opt out of Secure Communities, the program jointly administered by the Justice Department and the Department of Homeland Security, which automatically forwards information about arrestees to ICE. ${ }^{181}$

Among the largest challenges posed by crimmigration may be keeping the government's treatment of noncitizens reasonably visible, and laying down new lines of responsibility for decisions taken both with regard to individual immigrants and with regard to the overall operation of the system. Compare the following three stories:

In October 20ro, Juan Agreda-Chindoy, who is apparently a licensed medicine man in Columbia, arrived at a Houston airport with vials of ayahuasca, a plant extract used in traditional, religious healing ceremonies. Ayahuasca contains a hallucinogenic compound called dimethyltryptamine (DMT), which is a controlled substance in the United States. Customs agents in Houston found out what Agreda-Chindoy was carrying because when they asked him whether he was bringing in medicines, he said yes, and he showed them the vials. He explained that he was bringing the medicine to friends in Oregon for use in treating heroin addicrion. Nonetheless, when the agents determined that the potion in the vials contained DMT, they arrested Agreda-Chindoy for drug trafficking. He was jailed and charged in federal courr. ${ }^{182}$ His arrest caused an uproar in Columbia. Supporters set up a website, solicited donations, and hired a defense attorney. Within a month, the charges against Agreda-Chindoy were dropped. ${ }^{183}$

One reason the matter was resolved relatively quickly, and happily, is that it was clear all along who would decide whether the charges should be dropped: José Moreno, the United States Attorney for the Southern

18. See supra note 103.

182. See Susan Carroll, Columbian Healer Held as a Dealer in Houston Cell, Houston Chron., Nov. 6, 2010, at Ar.

183. See Susan Carroll, Charges Dropped Against Columbian Medicine Man, Houston Chron., Nov. 16, 2010, at B2. 
District of Texas. And it is clear who has ultimate responsibility for any systemic changes in prosecutorial policy that might prevent future cases like the arrest of Agreda-Chindoy: the Attorney General of the United States, Eric Holder.

In September 2oro, Steve Li, a twenty-year-old nursing student in San Francisco, was arrested by ICE and placed in an immigration detention center in Arizona. Li had come to the United States from Peru with his parents when he was twelve; his parents had earlier immigrated to Peru from China. Li's parents did not tell $\mathrm{Li}$ that they had only tourist visas to enter the United States, and in the years that followed they never told him that they were in the United States illegally. They did not tell him, when he turned fifteen, that their application for asylum in the United States had been denied. After ICE arrested Li, along with his parents, in September 2010, it began proceedings to deport $\mathrm{Li}$ to Peru and his parents to China. The Asian Law Caucus, a public-interest law office in San Francisco, orchestrated appeals on Li's behalf to Senators Boxer and Feinstein, and those appeals resulted in a temporary delay in Li's deportation. ${ }^{184}$

Blocking Li's deportation was more complicated than getting the criminal charges against Agreda-Chindoy dismissed, because the immigration bureaucracy is less transparent than the criminal justice bureaucracy: it was unclear, and remains unclear, which officials were responsible for deciding whether to proceed with Li's deportation. It was clear, though, that the decision would be made by ICE.

In early 2010, Tracey Washington and her two sons, aged five and thirteen, were ordered deported from United States on the grounds that they had overstayed their visa. Washington had moved to the Unired States from Australia in February 2009 to be with Charles Washington, whom she had met on an earlier trip to the United States. The couple married in April 2009. Federal immigration officials reportedly told them, inaccurately, that there was no deadline for Tracey to apply for permanent residency. The Washingtons were saving up for the $\$ 3,000$ filing fee when Tracey's thirteen-year-old son punched another child and took 46 cents. Police took the boy to juvenile hall on charges of assault, robbery, and extortionfelonies triggering mandatory reporting to ICE under a policy promulgated

184. See Jessica Kwong, Steve Li, City College Student, Awaits Deportation, S.F. Chron., Nov. 2, 2010, at A3; Jessica Kwong, Freed Student Steve Li Returns to S.F., S.F. Chron., Nov. 23, 2010, at AI. 
by then-Mayor Gavin Newsom in 2008. City supervisors passed an ordinance in November 2009 that would have delayed reporting until a youth was actually convicted of a felony, but the mayor refused to implement it, saying it violated federal law. In December 2009, Tracey Washington applied for legal residency but was told that it was too late; the deadline for applying was thirty days following her arrival into the country. Later immigration officials said they would reconsider, but the process would take four months. Tracey and her sons would be back in Australia by then, legally barred from returning to the United States for three to ten years. But the Asian Law Caucus publicized their case and won a temporary reprieve of the deportation orders, and several weeks later Tracey and her sons were granted permanent residency. ${ }^{185}$

Pinpointing responsibility for the treatment of Tracey Washington, and for the policies that will govern any future cases like hers, is extraordinarily difficult. Not only are the responsible officials nameless and invisible, it is not even clear which agencies, or which levels of government, bear responsibility - whether this matter should be laid at the feet of the San Francisco Police Department, Mayor Newsom, or federal immigration officials. The mayor's office, unsurprisingly, shifted blame to ICE: "We notify federal authorities about undocumented felony arrests," a spokesman for Newsom explained, "and they sort out the immigration issues." 186 But ICE, as we have seen, describes itself as "partnering" with local law enforcement to remove "dangerous criminals" from the country. $^{187}$

The accountability deficit in the emerging system of crimmigration is only partly a function of ad hoc instrumentalism - only partly a function, that is to say, of the treatment of criminal and immigration procedures and penalties and interchangeable tools to be invoked strategically, on a case-by-case basis, by low-level officials. It is also, in part, a function of the opacity of the crimmigration system: the difficulty in determining which officials, or even which agencies, are responsible for particular decisions and policies. The opacity, in turn, is partly a consequence of the sheer

185. See Bob Egelko, Deportations to Tear Apart S.F. Family, S.F. Chron., Mar. 2, 2010, at $\mathrm{Cr}$; Bob Egelko, Boy Who Punched Schoolmate Won't Be Deported, S.F. Chron., Apr. 22, 2010, at Ci; Phelan, supra note 78.

186. Bob Egelko, Family Facing Deportation Breakup Wins Reprieve, S.F. Chron., Mar. 3, 2010, at Ar (quoting mayoral spokesman Tony Winnicker).

187. See supra text accompanying notes I02- 5 . 
complexity of the merged system of criminal and immigration enforcement: the multiple points of intersection between the parallel enforcement schemes; the blurred lines of responsibility between local, state, and federal authorities; the criss-crossing arrangements among immigration officials, law enforcement agencies, and private contractors; the deputizing of Border Patrol attorneys as prosecutors and local police as immigration agents; and so on. But the opacity is also, in part, a consequence of ad hoc instrumentalism. The activities of low-level officials tend to be more dispersed, less visible, and harder to monitor than the activities of their superiors. By pushing decision making down the chain of command, ad hoc instrumentalism tends to reduce transparency. Partly because of the complexity of the merged system of criminal and immigration enforcement, and partly because of its embrace of ad hoc instrumentalism, the system is even more opaque than the immigration system standing alone-which is saying something.

In addition to ad hoc instrumentalism and opacity, a third factor also undermines accountability at the intersection of criminal justice and immigration enforcement: the selectivity of the merged system of crimmigration. Not everyone is vulnerable to the use of immigration procedures as a parallel system of crime control, and not everyone is subject to prosecution for criminal violations related to immigration: only noncitizens. Noncitizens are, of course, a politically disempowered group: not only do they tend to be poorer than cirizens, less knowledgeable about the political process, and less integrated into their communities, but they literally have no vote. That is why state policies that discriminate against resident aliens are generally subject to heightened scrutiny under the Equal Protection Clause. ${ }^{188}$ Because noncitizens are politically disempowered, and because crimmigration operates only against noncitizens, we should not expect the normal political checks that operate, for example, on the criminal justice system, to operate on crimmigration. The oxen of the electorate are not being gored. However well or poorly the political process operates to keep criminal justice fair and effective (a matter of considerable debate ${ }^{189}$ ),

188. See Plyler v. Doe, 457 U.S. 202 (1982); Graham v. Richardson, 403 U.S. 365 (1971); but cf. Matthew v. Diaz, 426 U.S. 67 (1976) (applying rational basis review to federal discrimination on the basis of citizenship).

189. Compare, e.g., Stuntz, Political Constitution, supra note 177, with, e.g., Franklin E. Zimring, Gordon Hawkins, \& Sam Kamin, Punishment and Democracy: Three Strikes and You're Out in California (200I); David Alan Sklansky, Killer Seatbelts and Criminal 
those processes are likely to prove even worse at regulating the intersection of criminal justice and immigration enforcement.

It is worth noting that the "back door sentencing" regime of parole revocation suffers from some of the same accountability deficits as crimmigration. Like crimmigration, the use of parole revocation as an alternative system of crime control relies on ad hoc instrumentalism, is implemented through bureaucratic machinery less transparent than the normal processes of criminal justice, and applies selectively to a politically disempowered population-in this case, ex-felons. Of even greater concern, the population of ex-felons looks in many ways like the population of noncitizens. Both groups are disproportionately nonwhite, disproportionately poor, disproportionately young, and disproportionately male. More and moreespecially in the American Southwest, which is on the cutting edge of nationwide demographic trends-both groups are disproportionately Latino. Politically disempowered groups have always been policed differently, and more harshly, but we may be moving toward a society where the differentiation in policing systems is, in some ways, even more extreme: where certain disfavored subgroups are policed through the ad hoc, instrumental invocation of range of specialized procedural systems that all tend toward the opaque and categorically exempt the social and political mainstream.

All of this suggests that as the boundary between criminal law and immigration continues to blur, it will be particularly important to find ways to bolster accountability at the intersection of the systems. That could be done, in theory, by reining in ad hoc instrumentalism (perhaps through some kind of reenergized rhetoric about the rule of law) or by reducing the selectivity of crimmigration (through, say, some set of rules making citizens as well as noncitizens subject to deportation and other immigration proceedings). But neither of those developments seems likely to materialize, and the second seems undesirable. The best way to strengthen accountability in crimmigration is more straightforward: by making the system, and its lines of responsibility, more transparent.

Some of that is already happening, of its own accord. Under pressure from immigrant groups and civil rights activists, for example, ICE has made

Procedure, 119 Harv. L. Rev. F. 56 (2006); Donald A. Dripps, Criminal Procedure, Footnote Four, and the Theory of Public Choice: Or, Why Don't Legislatures Give a Damn About the Rights of the Accused?, 44 Syracuse L. Rev. 1709 (1993). 
it easier to locate and to track individuals in immigration detention-a development that will make it easier to uncover and to document how fairly and appropriately particular cases within the system are handled, although it may not help pinpoint responsibility for any injustice or abuse. ${ }^{190}$ More interestingly, state governors-poised midway between the politics of local crime control and the mandates of federal immigration-are assuming more and more responsibility for the fairness and effectiveness of enforcement actions directed against criminal aliens. Gubernatorial pardons are becoming, by default, a chief tool for avoiding the unjust deportation of aliens convicted of crimes that trigger mandatory removal from the United States. ${ }^{191}$ Increasingly, gubernatorial decisions to sign onto, or to opt out of, the Secure Communities program-providing automatic transmission to ICE of identifying information regarding all arrestees-receive heavy media scrutiny and public attention. ${ }^{192}$ And enforcement practices regarding crimmigration more broadly are playing conspicuous roles in gubernatorial elections. Governor Jan Brewer of Arizona made her state's efforts to combat criminal aliens the centerpiece of her successful bid for reelection. ${ }^{193}$ In contrast, Republican Meg Whitman's campaign to be governor of California appears to have been derailed in part by her inability to stake out a credible position on immigration questions, acceptable both to hard-liners within her own party and to the state's growing group of moderate Latino voters. ${ }^{194}$

State-level decisions about crimmigration are even reverberating upward, forcing federal officials to soften some policies regarding noncitizens suspected or convicted of crimes. ICE has taken steps, for example,

190. See supra, text accompanying notes 89,90 .

19I. See, e.g., Kirk Semple, Governor Pardons Six Immigrants Facing Deportation Over Old Crimes, N.Y. Times, Dec. 6, 2010, at A25.

192. See, e.g., Russell Contreras, Activists Protest Patrick's Plan for Immigration Checks; State Police Would Join U.S. Program, Boston Globe, Dec. 23, 2010, at Ar2; Tim Hoover, Governor Signs on with Secure Communities Program, Denver Post, Jan. 5, 201r, at AI; Preston, supra note r03; Julia Preston, Immigration Program is Rejected By 3 rd State, N.Y. Times, June 7, 20II, at A13; Kirk Semple, Paterson and Federal Officials Reach Pact on Immigration, N.Y. Times, Dec. 31, 2010, at Arg.

193. See, e.g., Rhonda Bodfield, Brewer Rides to Easy Win Over Goddard for Top Job, Ariz. Daily Star, Nov. 3, 2010, at A9.

194. See, e.g., Peter Schrag, Bashing "Them" Again; Republican Steve Poizner Hopes that Waving the Bloody Shirt of the Illegal Immigration Issue will Close the Gap on Meg Whitman, L.A. Times, Mar. 2I, 2010, at A31; George Skelton, Whitman Paid a High Price for Latino Distrust of GOP, L.A. Times, Dec. 20, 2010, at $A 2$. 
to focus its deportation efforts under Secure Communities more narrowly on immigrants convicted of serious crimes, and to give government agents and government lawyers more leeway to defer or forego deportations on equitable grounds-steps that the agency's head said were responsive to "the concerns raised by the governors" along with "members of Congress and community groups." ${ }^{\prime 95}$ As significant as these policy changes themselves, and the political realities credited with helping to bring them about, was the mode of their dissemination: a public announcement from the Director of ICE, taking explicit responsibility for the change of course.

But pardons and other gubernatorial interventions, even coupled with policy announcements from the Director of ICE, can serve only to circumscribe the broad limits of crimmigration. For the day-to-day workings of the system to become more accountable will require clearer lines of responsibility regarding individual enforcement decisions and local policies. That is to say, it will require transparency and accountability at administrative levels well below the head of the agency. Responsibility for the treatment of Steve $\mathrm{Li}$ and Tracey Washington should be as easy to trace as responsibility for the treatment of Juan Agreda-Chindoy. For that to happen, officials responsible for individual crimmigration decisions will need to become as visible and publicly identifiable as local United States Attorneys and Assistant United States Attorneys. It would be a mistake to exaggerate the transparency and accountability of federal prosecutorial decisions, but it would be just as much of a mistake to ignore how much less transparent and accountable crimmigration decisions remain.

\section{CONCLUSION}

There is a risk, of course, that making crimmigration more accountable could wind up making it uglier. If popular sentiment is swinging heavily

195. Julia Preston, U.S. Pledges to Raise Deportation Threhold, N.Y. Times, June I8, 2011, at $\mathrm{Au}_{4}$ (quoting John Morton, Director of ICE). For the specific terms of the new policy, see Memorandum from John Morton on Exercising Prosecutorial Discretion Consistent with the Civil Immigration Priorities of the Agency for the Apprehension, Detention, and Removal of Aliens, June 17, 201I, www.ice.gov/doclib/secure-communities/pdf/ prosecutorial-discretion-memo.pdf. 
toward nativism, a more transparent, and more transparently attributable, set of enforcement decisions could be a harsher and less humane set of decisions. Just as democracy is often thought a threat to fair and effective criminal justice, ${ }^{196}$ accountability may be seen as a problem rather than a solution in the area of crimmigration.

There are grounds for cautious optimism, though, about the likely effects of greater transparency where criminal justice overlaps with immigration. Shifting demographics, and especially the growth of Latino and Asian American populations, are gradually strengthening the hands of groups friendly to the interests of immigrants. It is probably no accident that SB 1070 was adopted last year in Arizona rather than California, New Mexico, or Texas-states where the Latino share of the electorate is further along the growth curve that it appears to be following in Arizona, too, as well as in the nation as a whole. ${ }^{197}$ Arizona is ahead of the nation on this trajectory, but a decade or so behind California, which had its bout of anti-immigrant legislating in the 1990 s. ${ }^{198}$ And even in Arizona, antiimmigrant sentiment may be softening: the state legislator most closely tied to SB 1070 failed to find support for follow-on legislation aimed at denying citizenship to the children of undocument immigrants and then lost a recall election. ${ }^{199}$ So far, moreover, cracks in the opacity of immigration enforcement appear to have been exploited mainly by groups concerned with the humane treatment of noncitizens.

Even if the prospects are bleaker than I have suggested for an informed and humane politics about the treatment of noncitizens, there may still be a case for making crimmigration transparent. The situation here is different than with criminal justice outside the context of immigration. There, we have a set of constitutional protections for suspects and defendants that might be thought to supplement or to substitute for democratic accountability. Many of the debates in criminal procedure scholarship over the past several decades have been about the relative merits of what can be

196. See, e.g., Zimring, Hawkins \& Kamin, supra note 189; Dripps, supra note 189.

197. See Pew Hispanic Center, Statistical Portrait of Hispanics in the United States, 2009, tbl. I4 (2010), pewhispanic.org/files/factsheets/hispanics2009/Tabler4.pdf; William H. Frey, Will Arizona Be America's Future? (online posting, Apr. 28, 2010), www.brookings. edu/opinions/2010/0428_arizona_frey.aspx.

198. See, e.g., Sklansky, supra note 123.

199. See Marc Lacey \& Katherine Q. Seelye, Recall Election Claims Arizona AntiImmigration Champion, N.Y. Times, Nov. 10, 2011, at A22. 
seen as two different mechanisms of accountability: on the one hand, representative democracy, and on the other, the rule of law, which in this context has meant judicial protection of constitutional rights. In crimmigration, though, there is no alternative mechanism of accountability, and none seems in the offing. The social and political circumstances that facilitated the emergence of a robust set of constitutional protections for criminal suspects and defendants in the middle decades of the twentieth century are not duplicated today for immigrants, especially not for immigrants suspected of involvement in crime. If crimmigration is to become more accountable, we may need to rely on politics at least as much as law. 